\title{
Study of Solvent and Catalyst Interactions in Direct Coal \\ Liquefaction
}

Michael T. Klein (Principal Investigator), William H. Calkins (Co-Principal Investigator), Jasna Tomic (Post-Doctoral Fellow)

Center for Catalystic Science and Technology

Department of Chemical Engineering

University of Delaware

Newark, DE 19716

Final Report

October 4, 2000

Contract Number: DE-FG26-97FT97264

Prepared for the Department of Energy 


\section{Executive Summary}

To provide a better understanding of the roles of a solid catalyst and the solvent in Direct Coal Liquefaction, a small reactor was equipped with a porous-walled basket which was permeable to the solvent but was not permeable to the coal or solid catalyst. With this equipment and a high volatile bituminous coal it was found that direct contact between the catalyst in the basket and the coal outside the basket is not required for catalyzed coal liquefaction. The character of the solvent in this system makes a significant difference in the conversion of the coal, the better solvents being strong donor solvents.

Because of the extensive use of thermogravimetric analysis in this laboratory, it was noted that the peak temperature for volatiles evolution from coal was a reliable measure of coal rank. Because of this observation, a variety of coals of a range of ranks was investigated. It was shown in this work that measuring the peak temperature for volatiles evolution was a quite precise indicator of rank and correlated closely with the rank value obtained by measuring vitrinite reflectance, a more difficuit measurement to make.

This prompted the desire to know the composition of the volatile material evolved as a function of coal rank. This was then measured by coupling a TGA to a mass spectrometer using laser activation and photoionization detection TG-PI-MS. The predominant species in volatiles of low rank coal turned out to be phenols with some alkenes. As the rank increases. the relative amounts of alkene and aromatic hydrocarbons 
increases and the oxygenated species decrease. It was shown that these volatiles were actually pyrolytic products and not volatilization products of the coal.

Solvent extraction experiments coupled with Thermogravimetric-photoionizationmass spectrometry (TG-PI-MS) indicated that the low boiling and more extractable material are essentially similar in chemical types to the non-extractable portions but apparently higher molecular weight and therefore less extractable. 


\section{Table of Contents}

Executive Summary .............................................................

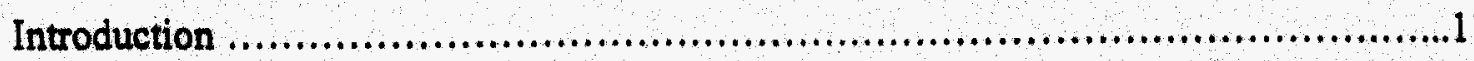

Experimental Section ............................................................

Results and Discussion ...........................................................

A. Determination of the Role of the Solid Catalyst........................7

B. The Role of Liquefaction Solvent ....................................10

C. Determination of Coal Rank by Themogravimetric Analysis.......12

D. Composition of Volatile Matter of Different Rank Coals .............15

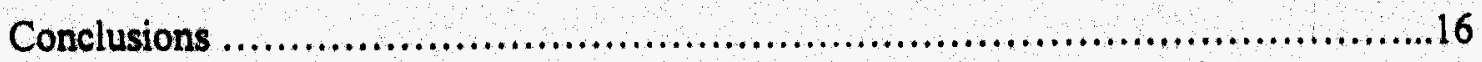

Publications ..................................................................... 18

References ....................................................................... 18

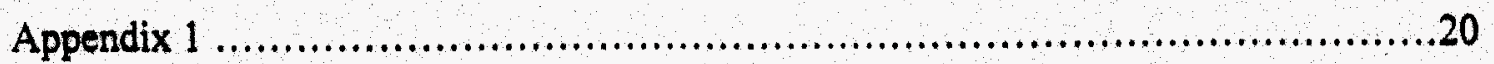

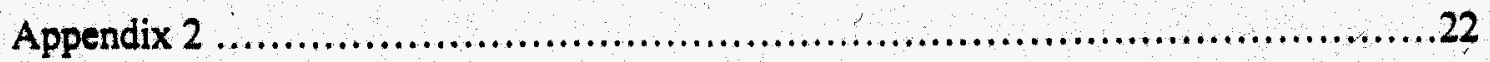




\section{Introduction}

Despite many years of research on Direct Coal Liquefaction, there are still some aspects of the process which are not fully understood and yet could have important implications for process improvement. Among these questions are the roles of the solid catalyst and the solvent. Neavel (1) showed that hydroaromatic solvents in direct liquefaction in the absence of a catalyst act primarily as a donor of hydrogen atoms to the free radicals formed as the coal is broken down thermally under coal liquefaction conditions. This minimizes degradative reactions of these radicals which otherwise form insoluble and unreactive products. Much emphasis in modern coal liquefaction studies however has been on liquefaction in the presence of both a donor solvent and a solid catalyst such as nickel/molybdenum or cobalt/molybdenum on an alumina support. Tomlison (2) and others (3.4) have shown that adding a solid catalyst in coal liquefaction produced higher conversion and oil yields of higher quality. Weller and Pelipetz (5) also observed the beneficial effect of added catalyst but pointed out the importance of catalyst distribution on liquefaction behavior with the best results obtained with impregnation of the coal with a catalyst solution.

When a solid catalyst is used, the role of the catalyst is not so clear. Mass transfer consideration would suggest that contact between solid coal and solid catalyst in a liquid medium would be difficult and probably not very effective. Gorin (6) postulated that the role of the catalyst is primarily to rehydrogenate the spent hydrogen donor solvent. This is an important question. If the role of the catalyst is more directly involved in the liquefaction process itself, an open question concerning the role of the 
solid catalyst is whether intimate contact between the catalyst and the coal particles is necessary.

Much research effort (7-9), some supported by DOE, has been devoted to producing ultrafine catalyst particles in order to get better contact between the catalyst and the coal but has had only limited success. Since producing ultrafine catalysts is a somewhat difficult and expensive process, it is important to avoid that step if possible. One objective of this project therefore is to determine whether intimate contact between catalyst and coal is necessary in the liquefaction process. If it is not. since catalyst have been shown to increase the liquefaction rate, what is the process of communication within the solvent between the catalyst and the coal? This raises the question of the actual role of the solvent in this system.

Many years ago, Weller and Pelipetz (5) and Hawk and Hitesinue (10) investigated a range of metal catalysts for liquefaction of coal in the absence of added solvent. Since that initial work, others have also run solvent-free liquefactions (11). In such a solventfree system, the catalyst was impregnated onto the coal (incipient wetness method). In these cases it is not known whether direct contact between the coal and the catalyst is taking place or whether the low molecular weight substances in the coal the so-called mobile phase) are acting as a solvent in the liquefaction process.

It was the objective of this project to shed some light on the roles of the catalyst and solvent in the liquefaction process. In doing so, the liquefactions were run with the catalyst separated from the coal by means of a porous tubular basket that was permeable to the solvent but not to the coal or catalyst particles. 


\section{Experimental section}

Coal. In the study investigating the interaction of the coal and the catalyst in the liquefaction system Illinois \#6 (DECS 24) from the Penn State Coal Bank was used. This coal has been used in many coal liquefaction studies, both laboratory and pilot plant, in the past and is a suitable candidate for commercial coal liquefaction processes should such processes become economically viable. The coal was used as received and stored under argon. Occasional thermogravimetric analyses (TGA) were conducted on a sample of the coal to check for moisture content. The proximate and ultimate analyses of the coal are provided in Appendix 1.

Catalyst. Two solid catalysts were used both obtained from Consolidation Coal Company: Amocat 1C with $2.77 \mathrm{wt} \% \mathrm{Ni}$ and $9.93 \mathrm{wt} \% \mathrm{Mo}$ (unsulfided) and Shell 324 with $3.19 \mathrm{wt} \% \mathrm{Ni}$ and $12.89 \mathrm{wt} \% \mathrm{Mo}$. The catalysts were in the shape of pellets with a diameter of $2 \mathrm{~mm}$ and length on the order of several $\mathrm{mm}$. The catalysts were presulfided in different ways: 1) treatment of the catalyst with $1 \mathrm{~g}$ of methyl disulfide before loading into reactor, and 2) treatment of the catalyst in the porous basket in the reactor with $\mathrm{H}_{2} \mathrm{~S}$ with programmed heat-up to reaction temperature (around $400^{\circ} \mathrm{C}$ ).

Solvents. Several solvents were used for the liquefaction experiments. Tetralin, methylnaphthalene, and decalin, as examples of solvents of different hydrogen donor strengths. Other solvents tested were 9,10-dihydrophenanthrene and 1,2dihydronaphthalene. In some cases, mixtures of the latter solvents with tetralin were used because of limited supply of the dihydrosolvents.

Apparatus and Procedure. To determine whether close contact between catalyst and coal is necessary, a series of liquefaction runs were made using our short contact time 
batch reactor (12) but with the solid catalyst contained in a porous stainless steel basket in the reactor. The porosity of the basket was to be such that the coal could not contact the catalyst directly but the basket would be permeable to the solvent. Considerable effort was devoted to design and construction of the basket that had to fit into our liquefaction reactor (Fig 1) but also allowed free passage of solvent to the catalyst. Several baskets were constructed of stainless steel tubing (from Mott Corporation) and were of different porosity: $0.5 \mu \mathrm{m}, 2.0 \mu \mathrm{m}$, and one with holes which would not pass coal particles larger than 30 mesh. The $0.5 \mu \mathrm{m}$ basket restricted the solvents flow excessively but the others appeared to work satisfactorily.

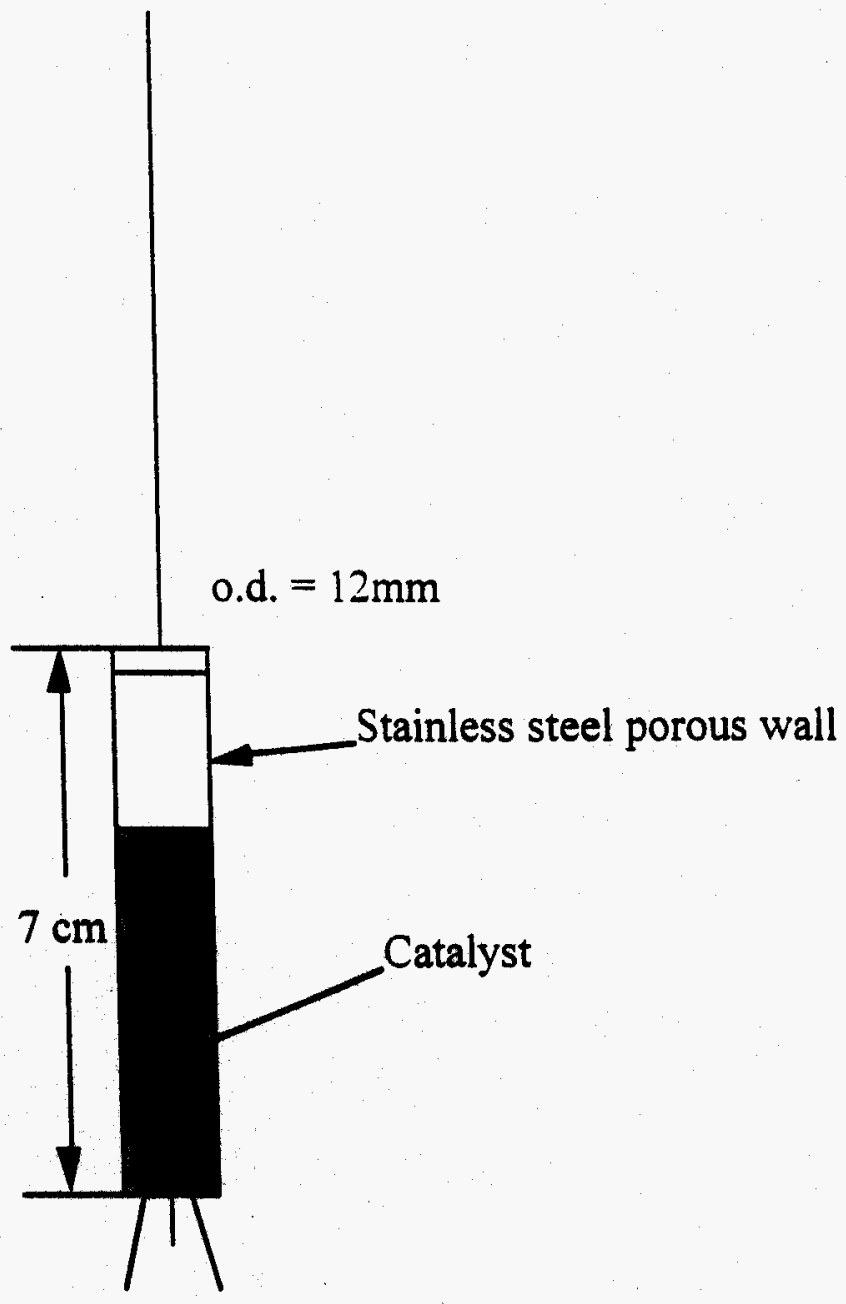

Figure 1. Stainless steel basket for solid catalyst. 
The short contact time reactor which was slightly modified from its previous design (see references 12,13). The schematic diagram of the reactor system is shown in Figure 2. The $50 \mathrm{~cm}^{3}$ reactor is connected through a preheater coil to a blow case which is charged with coal and solvent. A thermocouple is connected with a quick-connect to the top of the reactor. The quick-connect assembly was added so that the basket with the catalyst could conveniently be placed inside of the reactor. The porous stainless steel basket, loaded with $1-1.5 \mathrm{~g}$ of fresh catalyst, is placed inside the reactor before each experiment.

In operations. the preheater and reactor are brought up to the desired temperature by immersion in a Techne IFB-52 fluidized sand bath. High-pressure hydrogen or nitrogen is used to provide the driving force to deliver the reaction mixture from the blow case through the preheater into the reactor. Agitation of the reaction mixture is accomplished by bubbling hydrogen or nitrogen gas through the mixture from the bottom. At the end of the reaction, the high-pressure gas is again used to drive the contents through the precooler into a receiver both of which are immersed in a water bath.

Each experiment used a nominal weight of $+\mathrm{g}$ of coal and of $32 \mathrm{~g}$ of solvent (solvent to coal ratio 8:1). An amount of $1-1.5 \mathrm{~g}$ of catalyst was loaded into the basket and placed in the reactor at the beginning of the heat-up period. Most reactions were conducted for 30 minutes, unless otherwise indicated at a temperature range of 390 to $420^{\circ} \mathrm{C}$. Control experiments were conducted without the catalyst present (empty basket). 
Figure 2. Valve Control Diagram of Short Contact Time Reactor

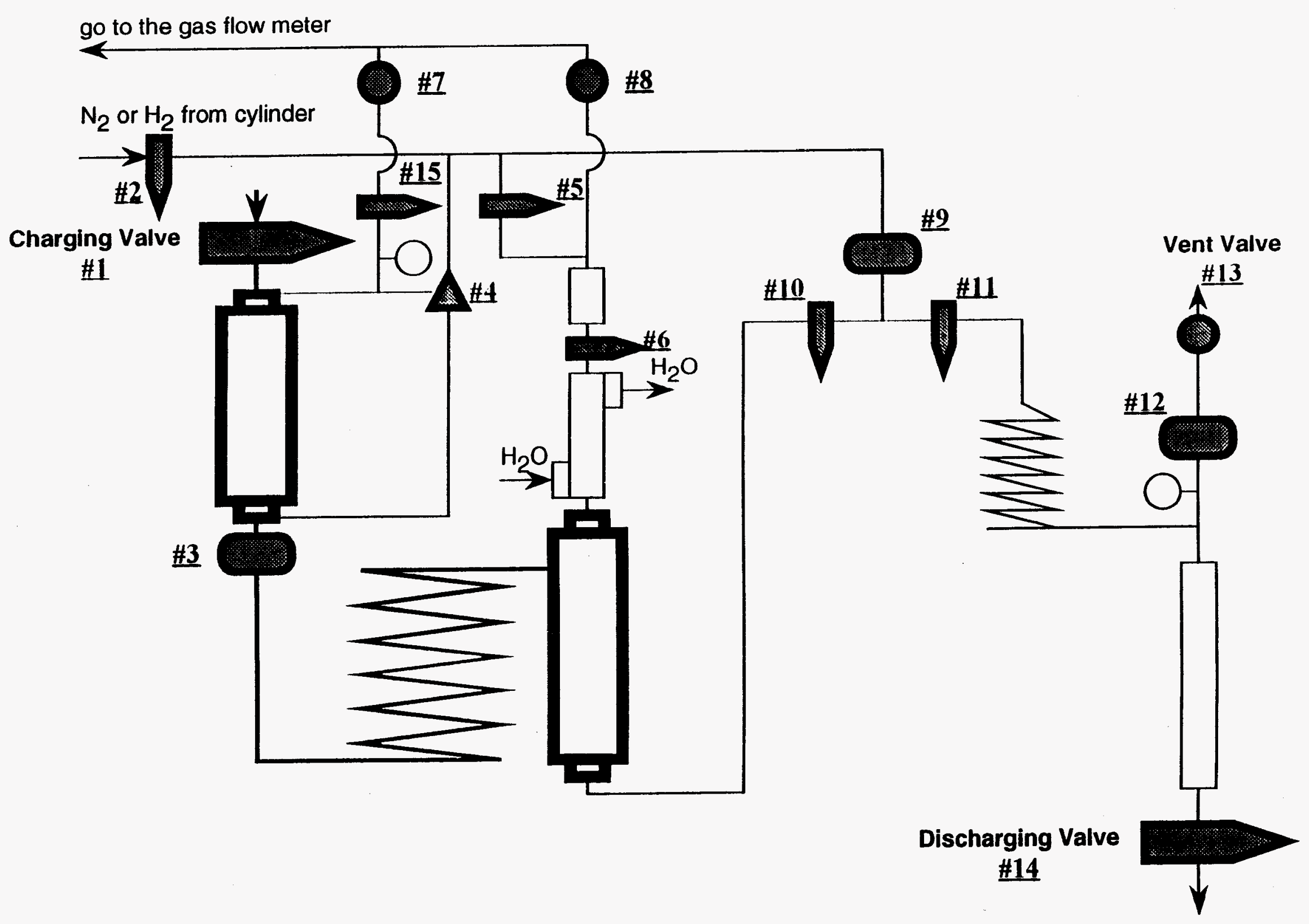


The collected product mixture was filtered and the solid residue was washed with cold fresh tetralin thoroughly and dried in a vacuum oven for 24 hours. The dried solid residue was analyzed by thermogravimetric analyzer Model 2050 TGA (TA Instruments, New Castle, DE). The liquefaction residues were analyzed for ash content and compared to the initial content of ash (mineral matter) in the coal. The coal conversion was calculated based on the ash contents using the following formula:

$$
X(\text { dafivt } \%)=\frac{1}{1-A o} \times\left(1-\frac{A o}{A s}\right) \times 100 \%
$$

where Ao and As are weight fractions of ash (derived from mineral matter) in a control sample of coal and the liquefaction residue, respectively.

The liquid product was analyzed by gas chromatography for amount of tetralin, naphthalene, or decalin.

\section{Results and Discussion}

\section{A. Determination of the Role of the Solid Catalyst}

A series of liquefaction runs were made using tetralin as the solvent, 30 minutes reaction times, ca. $420^{\circ} \mathrm{C}$ and 1000 psi hydrogen pressure. The catalyst basket was run without catalyst and with Shell 324 or with a similar weight of Amocat 1C catalyst. Table 1 lists the coal conversion for the experiments. The results are listed in order of increasing temperature of reaction. 
Table 1. Coal conversion for Illinois \#6 with tetralin with and without catalyst in the basket.

\begin{tabular}{lccccc}
$\mathrm{T},{ }^{\circ} \mathrm{C}$ & $\begin{array}{c}\mathrm{t} \text {, min } \\
\text { P, psig }\end{array}$ & Catalyst & Basket & $\begin{array}{c}\text { Conv, } \\
\text { wt\% }\end{array}$ \\
\hline 390 & 30 & $1000 \mathrm{H}_{2}$ & no & no & 46.3 \\
389 & 30 & $700 \mathrm{H}_{2}$ & Shell & $2.0 \mu \mathrm{m} / \mathrm{H}_{2} \mathrm{~S}$ & 48.2 \\
392 & 30 & $1000 \mathrm{H}_{2}$ & Shell & $2.0 \mu \mathrm{m} / \mathrm{H}_{2} \mathrm{~S}$ & 45.0 \\
411 & 30 & $750 \mathrm{H}_{2}$ & Shell & $2.0 \mu \mathrm{m}$ & 64.5 \\
410 & 30 & $850 \mathrm{H}_{2}$ & Shell & $2.0 \mu \mathrm{m} / \mathrm{S}$ & 57.4 \\
& & & & & \\
419 & 32 & $1000 \mathrm{~N}_{2}$ & no & $0.5 \mu \mathrm{m}$ & 57.9 \\
417 & 30 & $1000 \mathrm{H}_{2}$ & no & no & 56.1 \\
418 & 31 & $1000 \mathrm{H}_{2}$ & no & $0.5 \mu \mathrm{m}$ & 55.7 \\
417 & 30 & $1000 \mathrm{H}_{2}$ & Shell & $2.0 \mu \mathrm{m}$ & 57.2 \\
417 & 30 & $750 \mathrm{H}_{2}$ & Shell & $2.0 \mu \mathrm{m} / \mathrm{S}$ & 62.3 \\
& & & & & \\
421 & 30 & $1000 \mathrm{H}_{2}$ & no & $2.0 \mu \mathrm{m}$ & 55.4 \\
420 & 30 & $800 \mathrm{H}_{2}$ & Shell & $2.0 \mu \mathrm{m}$ & 61.3 \\
421 & 30 & $1000 \mathrm{H}_{2}$ & Shell & $30 \mathrm{mesh}$ & 59.7 \\
420 & 30 & $1000 \mathrm{H}_{2}$ & Amocat & $2.0 \mu \mathrm{m}$ & 65.2 \\
421 & 30 & $1000 \mathrm{H}_{2}$ & Amocat & $30 \mathrm{mesh}$ & 59.3 \\
\hline
\end{tabular}

One can concluded from this table that conversions with catalyst in the basket were higher by $5 \mathrm{wt} \%$ on average than without the catalyst in the basket. This trend is more pronounced at the higher reaction temperanures used in this study. This suggests that direct contact between coal and the catalyst is not necessary and that there must be transmission of active material, presumably hydrogen in some form, between the catalyst and the coal.

It should be noted that a similar liquefaction run was made with sulfided Shell catalyst in the basket under the same set of conditions but with 1000 psig nitrogen instead of hydrogen. The conversion observed under these conditions was $49 \%$ which compares favorably with runs made without catalyst. This is an added indication that the 
catalyst plays no role in the system when gaseous hydrogen is absent. In this case, the hydrogen for liquefaction is supplied entirely by the donor solvent.

We analyzed selected samples of the liquid filtrate after reaction by Gas Chromatogram in order to quantify the amount of tetralin and naphthalene in the liquid products. Gorin postulated (6) that the catalyst is participating in the hydrogenation of naphthalene produced from the tetralin and reports in the literature have shown that in catalytic liquefaction the amount of naphthalene produced from tetralin decreases compared with the liquefaction in the absence of catalyst (14-16). From Table 2, we can see the amounts of tetralin and naphthalene in the liquid product from catalytic and noncatalytic liquefaction and we do not observe the decrease in naphthalene in the product for catalytic liquefaction. The reason for this may be that the increase in coal conversion with a catalyst present in our case is not very large and thus the change in amount of naphthalene was not observed.

Table 2. Amount of tetralin and naphthalene in the liquefaction product. $\mathrm{T},{ }^{\circ} \mathrm{C} \quad \mathrm{t}, \mathrm{min} \mathrm{P}, \mathrm{psig}$ Catalyst $\begin{gathered}\text { Conv, } \\ \text { wt\% }\end{gathered}$ Tetralin, $\mathrm{g}$ Naph,

\begin{tabular}{lllclll}
\hline 419 & 30 & $\mathrm{~N}_{2}$ & no & 57.9 & 30.0 & 2.4 \\
421 & 30 & $\mathrm{H}_{2}$ & no & 55.4 & 27.5 & 2.5 \\
411 & 30 & $\mathrm{H}_{2}$ & Shell & 64.5 & 30.3 & 3.7 \\
420 & 30 & $\mathrm{H}_{2}$ & Amocat & 65.2 & 23.5 & 1.7 \\
\hline
\end{tabular}

We compared our current results to those of similar experiments with soluble catalyst, molybdenum naphthanate $(\mathrm{MN})$, which were conducted in this laboratory earlier (Table 3). Comparison of the conversion in Table 1 and Table 3 it is obvious that 
conversions with the soluble $\mathrm{MN}$ were higher. The reason for this may be the more limited rate of mass transfer of solvent through the basket wall when the solid catalyst is placed in the basket. This is not a limitation when a "soluble" catalyst is used.

Table 3. Coal conversion with soluble catalyst, molybdenum naphthanate.

\begin{tabular}{lcccc}
$\mathrm{T},{ }^{\circ} \mathrm{C}$ & $\mathrm{t}, \min$ & $\mathrm{P}, \mathrm{psig}$ & Catalyst & $\begin{array}{c}\text { Conv, } \\
\text { wt\% }\end{array}$ \\
\hline 390 & 30 & $\mathrm{~N}_{2}$ & no & 42.6 \\
390 & 30 & $\mathrm{H}_{2}$ & no & 46.3 \\
402 & 30 & $\mathrm{H}_{2}$ & $\mathrm{MN}$ & 71.2 \\
418 & 30 & $\mathrm{H}_{2}$ & $\mathrm{MN}$ & 77.1 \\
\hline
\end{tabular}

$\mathrm{MN}$ - molybdenum naphthanate catalyst

\section{B. Role of Liquefaction Solvents}

To better understand the role of the solvent in the presence and absence of the solid catalyst; a series of liquefaction runs were made with various soivents differing in hydrogen donor ability and the $2 \mu \mathrm{m}$ basket. The solvents used were :atralin. decalin, and methylnaphthalene. Clearly, the runs made with the stronger donor solvent (tetralin) gave higher conversions. It is interesting to note however, that the poorest of the hydrogen donor solvents (decalin) still gave appreciable conversion to liquid products and that in the presence of a catalysts in the basket, significantly by about $10 \mathrm{w} \%$, higher conversions were obtained than without the catalyst (see Table 4). 
Table 4. Coal conversion with decalin and methylnaphthalene with and without catalyst in the basket.

\begin{tabular}{lcccccc}
$\mathrm{T},{ }^{\circ} \mathrm{C}$ & $\mathrm{t}$ min & P,psig & Solvent & Catalyst & $\begin{array}{c}\text { Basket } \\
\text { wt\% }\end{array}$ & Conv, \\
\hline 425 & 30 & $1000 \mathrm{H}_{2}$ & Decalin & no & $2.0 \mu \mathrm{m}$ & 42.2 \\
418 & 30 & $1000 \mathrm{H}_{2}$ & Decalin & no & $2.0 \mu \mathrm{m}$ & 40.4 \\
425 & 32 & $700 \mathrm{H}_{2}$ & Decalin & Shell & $2.0 \mu \mathrm{m}$ & 49.9 \\
420 & 30 & $1000 \mathrm{H}_{2}$ & Decalin & Amocat & $2.0 \mu \mathrm{m}$ & 50.0 \\
\hline
\end{tabular}

$\mathrm{MN}$ - molybdenum naphthanate catalyst

Table 5. Coal conversion with methylnaphthalene with and without catalyst in the basket.

\begin{tabular}{lcccccc}
\hline 424 & 30 & $1000 \mathrm{H}_{2}$ & Me-Naph & no & $2.0 \mu \mathrm{m}$ & 59.0 \\
420 & 32 & $1000 \mathrm{H}_{2}$ & Me-Naph & no & $2.0 \mu \mathrm{m}$ & 55.2 \\
420 & 31 & $1000 \mathrm{H}_{2}$ & Me-Naph & Shell & $2.0 \mu \mathrm{m}$ & 54.8 \\
417 & 30 & $1000 \mathrm{H}_{2}$ & Me-Naph & Shell & $2.0 \mu \mathrm{m}$ & 54.8 \\
428 & 30 & $1000 \mathrm{H}_{2}$ & Me-Naph & Amocat & $2.0 \mu \mathrm{m}$ & 48.6 \\
412 & 30 & $\mathrm{H}_{2}$ & Me-Napth & no & no & 55.1 \\
412 & 30 & $\mathrm{H}_{2}$ & Me-Napth & MN & no & 66.4 \\
\hline
\end{tabular}

Me-Naph - methylnaphthalene

$\mathrm{MN}$ - molybdenum naphthanate catalyst

Methylnaphthalene (Table 5) on the other hand turns out to be a better hydrogen donor than decalin as seen from higher conversion in non-catalytic liquefaction, but shows little benefit from the presence of the catalyst in the basket. While methylnaphthalene appears to be a donor solvent, i.e. there is conversion of the coal; it does not appear to transmit hydrogen from the catalyst through the wall of the basket. The reason for this is not apparent but may be related to the fact that methylnaphthalene does not have a strong hydroaromatic character as do the other two solvents. 
Two presumably stronger donor solvents were tested: 1,2-dihydronaphthalene and 9,10-dihydrophenanthrene. In view of the cost of these two solvents, they were used in combination with tetralin. Coal conversion results with these solvents are listed in Table 6.

Table 6. Coal conversion with 1,2 dihydronaphthalene and 9,10 dihydrophenanthrene added to tetralin.

$\mathrm{T},{ }^{\circ} \mathrm{C} \quad \mathrm{t}, \min _{\mathrm{wt} \%}$ Tetralin Solvent Amount Catalyst Conv

\begin{tabular}{lllllll}
\hline 421 & 30 & 17.48 & $1,2-\mathrm{DHN}$ & 14.5 & Shell & 52.9 \\
419 & 30 & 24.4 & $9,10-\mathrm{PH}$ & 9.39 & Shell & 60.2 \\
\hline
\end{tabular}

The 1,2-dihydronaphthalene showed little or no increase in conversion over tetralin itself in the presence of Shell catalyst in the basket despite the fact that it is reported to be a stronger hydrogen donor (17). The 9,10-dihydrophenanthrene however did show increased conversion over that of pure tetralin. The latter solvent is a known strong hydrogen donor (17), stronger than either 1,2-dihydronaphthalene or tetralin, and presumably is transferring hydrogen through the basket wall from the catalyst to the coal.

\section{Determination of Coal Rank by Thermogravimetric Analysis}

It is well known that the susceptibility of coal to Direct liquefaction is strongly influenced by coal rank. The high rank coals do not give good liquefaction yields. One generally accepted and reliable measure of coal rank is mean maximum vitrinite reflectance. In the course of these studies, it was noticed however, that the temperature of maximum 
volatiles production of a coal is a reliable measure of coal rank. Since many laboratories are not equipped to run reflectance measurements, time was taken to develop a TGA method for coal rank that turned out to be as reproducible as the reflectance measurements (13).

A series of 28 coals whose elemental analysis, heat of combustion, vitrinite reflectance and vitrinite contents were known was analyzed by TGA. A model 51 TGA (TA Instruments, New Castle, DE) was used. Approximately $30 \mathrm{mg}$ sample of each coal was loaded in a quartz pan and mounted in the instrument. All TGA experiments were carried out in nitrogen at atmospheric pressure at a heating rate of $10^{\circ} \mathrm{C} / \mathrm{min}$. Figure 3 shows a correlation of the peak temperature with vitrinite reflectance. The correlation is very good with an $R^{2}$ value of 0.998 , indicating that peak temperature is an excellent measure of coal rank. The detailed description of the TGA experiments and the results can be found in reference (13). 


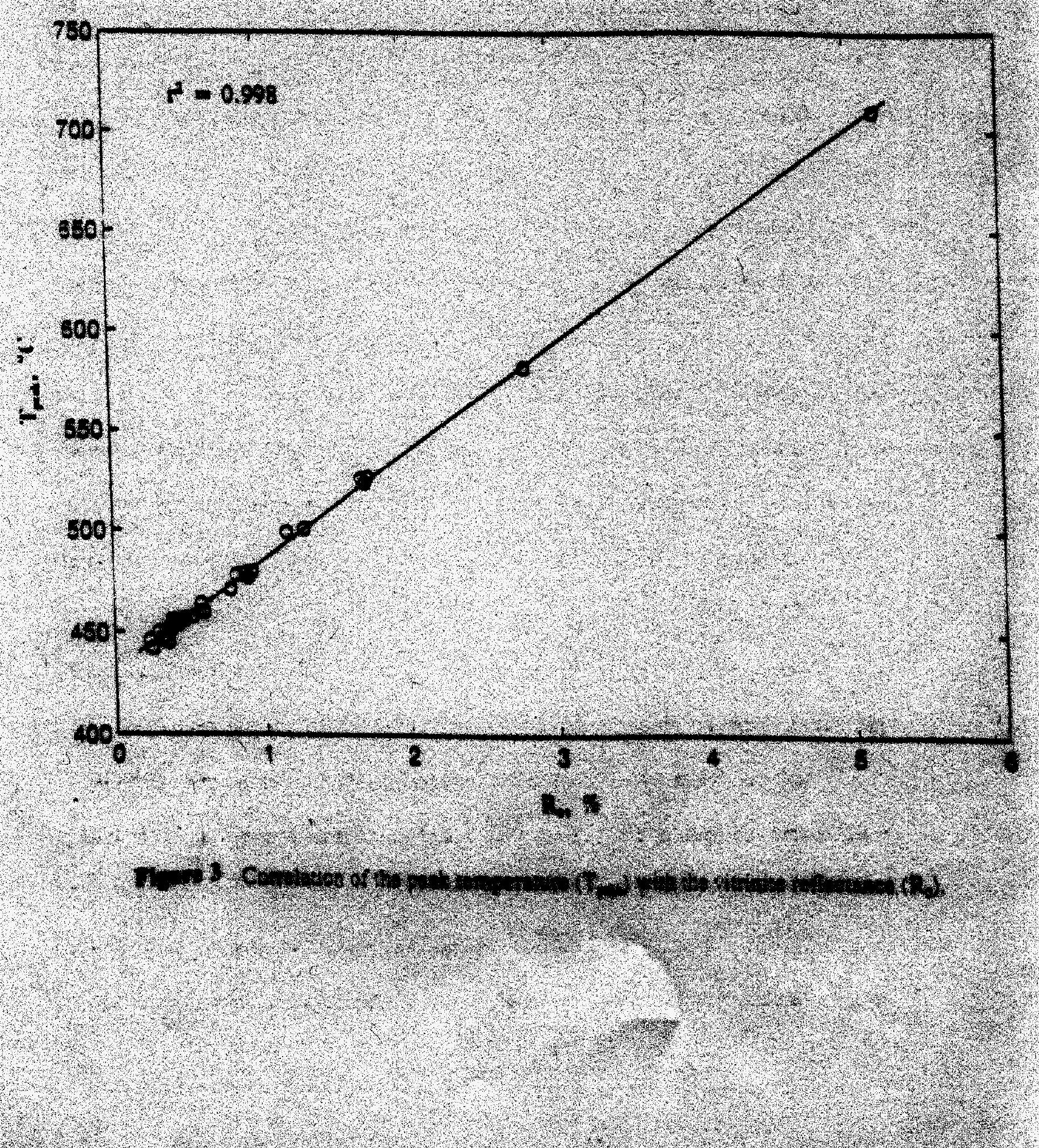




\section{Composition of Volatile Matter of Different Rank Coals}

Since the volatiles content of coal is one measures of coal rank and is related to the behavior of coal in direct coal liquefaction, it was of interest to learn the compositions of the volatiles in coal and how they vary with rank. To determine this, a TGA 2050 (TA Instruments, New Castle, DE) was attached to a reflectron time of flight (RTOF) mass spectrometer (R.M. Jordan Co., Grass Valley, CA).

Experiments were run on 17 different coals ranging in rank from lignite to low volatile bituminous. In addition, TGA/MS scans were run on coals extracted with tetrahydrofuran or pyridine in a soxhlet extractor for 72 hours and then dried under vacuum at $60^{\circ} \mathrm{C}$. Overall, the relative amounts of oxygen containing compounds such as $\mathrm{C}_{n} \mathrm{H}_{2 \mathrm{n}} \mathrm{O}$, phenols, and dihydroxybenzenes decrease with increasing coal rank. This decrease correlates well with the overall decrease in oxygen content of the coals with increasing rank. In addition, the relative amounts of aromatic hydrocarbons such as naphthalenes, phenathrenes and pyrenes increase with increasing coal rank. This increase in aromaticity of the evolved products correlates with an overall increase in the aromaticity of the coal. The full results description and results of the TG/PI-MS experiments can be found in Appendix 2 of this report.

Two separate experiments confirmed that the majority of compounds detected by TG-PI-MS were products of thermal bond cleavages and not thermal desorption products. First, it was determined that compounds spiked in coal evolved at much lower temperature than the same compounds evolved upon pyrolysis of the raw coal. In addition, laser desorption mass spectrometry of coal extracts revealed a higher molecular weight distribution of compounds than detected by TG-PI-MS. Therefore, these higher 
molecular weight compounds must pyrolyze in the TGA prior to detection by mass spectrometry.

Some of the volatile matter detected by TG-PI-MS may be removed from coal by solvent extraction with THF or pyridine. Although differences in the absolute amount of compounds evolved from the solvent extract, the coal after extraction, and the raw coal exist, the relative intensities of compounds detected by photoionization mass spectrometry remain virtually identical. This suggests that the volatile matter consists of a range of molecular weights with similar molecular structures. The lower-molecular weight material is more soluble, leaving a significant fraction of higher molecular weight volatile matter in the coal after solvent extraction. The main thermal degradation products are alkenes and aromatic hydroxy aromatic compounds. The evolved products identified by TG-PI-MS suggest the generally postulated structure of the macromolecular network of coal which is believed to contain clusters of aromatic rings separated by aliphatic, thioethers and ether bridges.

\section{Conclusions}

Using a reactor in which the coal is physically separated from the solid catalyst by a porous wall permeable to the hydrogen donor solvent, it was shown that direct contact between the catalyst and the coal is not required for catalyzed coal liquefaction. This occurs however only when there is a hydrogen atmosphere. The character of the solvent makes a significant difference, suggesting that there is transfer of hydrogen from the catalyst to the coal by way of the solvent, the better solvents being good hydrogen 
donors. In catalyzed direct coal liquefaction in the absence of solvent, the low molecular weight volatiles, which are largely oxygen compounds such as phenols, may be transferring the hydrogen from the gas phase via the catalyst to the coal.

Variation of volatile matter with coal rank was established using a thermogravimetric analyzer. The specific correlation that was established on more then 28 coals was the variation of the peak temperature of volatile matter evolution with coal rank. A smaller subgroup of these coals was analyzed by thermogravimetry photoionization mass spectrometry (TG-PI-MS) which enabled the characterization of classes of compounds that are part of the volatile matter. Several trends with coal rank were observed. First, the relative amounts of oxygen-containing compounds such as $\mathrm{C}_{n} \mathrm{H}_{2 \mathrm{n}} \mathrm{O}$, phenols, and dihydroxybenzenes decrease with increasing coal rank. Second, the relative amounts of aromatic hydrocarbons such as naphthalenes, phenanthrenes, and pyrenes increase with increasing coal rank. The higher thermal stability of aromatic relative to aliphatic compounds may contribute to the overall increase in the temperature of maximum volatile matter evolution with increasing coal rank.

Two separate techniques confirmed that the majority of compounds detected by TG-PI-MS were products of thermal bond cleavages and not thermal desorption. Part of the volatile matter detected by TG-PI-MS may be removed by solvent extraction with either THF or pyridine. The relative intensities of compounds evolved from the solvent extract, the coal after extraction, and the raw coal remain virtually identical. This suggests that the volatile matter consists of a range of molecular weights with similar molecular structures. 


\section{Publications}

The following publications have been issued or are in the process of being written as a results of work on this project.

1. "Thermogravimetric and Rock-Eval Studies of Coal Properties and Coal Rank," $\mathrm{H}$. Huang, S. Wang, K. Wang, M.T. Klein, W.H. Calkins and A. Davis Energy Fuels, 13, 396-400, 1999.

2. "Thermogravimetry-Photoionization Mass Spectrometry of Different Rank Coals," D.L. Zoller, M.V. Johnston, J. Tomic, X.Wang and W.H. Calkins Energy Fuels, 13, 1097-1104, 1999.

3. "Role of Solid Catalyst and Solvents in Direct Coal Liquefaction," . Tomic, X.Wang and W.H. Calkins, to be submitted for publications.

\section{References}

1. R.C. Neavel Fuel 1976, 55, 237.

2. G. Tomlinson, D. Gray, M. Neuworth in Proceedings of 1985 Intemational Conference on Coal Science, Sidney, Australia, 3-6, 1985.

3. Anderson, L.L. and Miin, T.C. Fuel Processing Technology 1986. I2. 165.

4. Anderson, R.P, Alexander, B.F., Wright, C.H. and Freel, J. Fuel 1985, 6t, 1564

5. Weller, S. and Pelipetz, M.G. Ind. Eng. Chem 1951, 43, 5, 1243.

6. Gorin, E. "Fundamentals of Coal Liquefaction," Ch. 27, in Chemistry of Coal Utilization, Second Supplementary Volume, (Ed. M.A. Eliott), Wiley Interscience, 1981.

7. Sato, Y, Kamo, T, Shiraishi, M., in Coal Science Vol II, Proceedings of the Eighth International Conference on Coal Science, (Eds. J.A. Pajares, J.M.D. Tascon) Elsevier, Amsterdam, 1259, 1995.

8. Kuriki, Y, Yumura, M.,Ohshima, S., Uchida, K., Ikazaki, F. in Coal Science Vol II, Proceedings of the Eighth International Conference on Coal Science. (Eds. J.A. Pajares, J.M.D. Tascon), Elsevier, Amsterdam, 1347, 1995. 
9. Zhao,J. Z. Feng, F. Huggins, and G.P. Huffman in Coal Science Vol II, Proceedings of the Eighth International Conference on Coal Science, (Eds. J.A. Pajares, J.M.D. Tascon), Elsevier, Amsterdam, 1331, 1995.

10. Hawk, C.O. Hiteshue, R.W. U.S. Bureau Mines Bulletin, 1965, No. 622.

11. Derbyshire, F.J., Davis, A., Epstein, M., Stansberry, P. Fuel 1986. 65, 1233-1240.

12. Huang, H., Calkins,W.H., Klein, M.T. Energy Fuels 1994, 8, 5304.

13. Huang, H., Wang, S., Wang, K., Klein, M.T., Calkins, W.H. Energy Fuels 1999, 13, 396-400.

14. Guin, J.A., Tarrer, A.R., Lee, J.M., Lo, L., Curtis, C.W. Ind. Eng. Chem. Process Des. Dev. 1979, 18, 371-376.

15. Rottendorf, H., Wilson, M.A. Fuel 1980, 59, 175-180.

16. Chow, C.K. Fuel 1981, 60, 1153-1158.

17. Curtis, C.W., Guin, J.A., Kwon, K. Fuel 1984, 63, 1404-1409. 
Appendix 1

Coal Analyses 
The Penn State Coal Sample Bank and Database

Illinois \#6 Seam (Herrin Seam) Macoupin County, IL
hrCb rank
Sample DECS-24

page 2 of 4

printed $8 / 24 / 95$

sampled $6 / 02 / 94$

\section{PROXIMATE ANALYSIS}

$\%$ Moisture $\frac{\text { as } \mathrm{rec}^{\prime} \mathrm{d}}{13.20}$

dry

daf $\quad$ dmmf(Parr)

$\%$ Ash

$\%$ Vol. Matter

11.62

13.39

\% Fixed Carbon

$35.44 \quad 40.83$

39.74

45.78

47.14

45.51

$52.86 \quad 54.49$

\section{- SULFUR FORMS}

\begin{tabular}{l}
$\%$ Pyritic \\
$\%$ Sulfate \\
$\%$ Organic \\
$\%$ Total \\
\hline
\end{tabular}

$\begin{array}{ll}\frac{\text { dry }}{2.64} & \frac{\text { daf }}{3.05} \\ 0.25 & 0.29 \\ 2.64 & 3.05 \\ 5.53 & 6.38\end{array}$

\section{MOISTURE}

$\%$ as received 13.20

$\%$ equilibrium 11.59

- ULTIMATE ANALYSIS

$\%$ Ash

\% Carbon

\% Hydrogen

$\%$ Nitrogen

\% Total Sulfur

$\%$ Oxygen (diff.)

\section{as $\frac{\mathrm{rec}^{\prime} \mathrm{d}}{11.62} \quad \frac{\mathrm{dry}}{13.39}$}

57.33

$3.98^{*}$

0.99

4.80

$8.07 *$

66.05

4.59

1.14

5.53

9.30

* excluding $H$ and $O$ in moisture

daf $\frac{\operatorname{dmmf}(P a r r)}{(17.50 \% M M)}$

$76.26 \quad 80.06$

$5.30 \quad 5.56$

$1.32 \quad 1.38$

6.38

10.74

12.99

Dry \% Chlorine $=0.14 \quad$ Dry $\%$ Carbon dioxide $=0.65$

\section{ELEMENTAL ANALYSIS}

\%) Carbon

$\%$ Hydrogen

$\%$ Nitrogen

\% Organic Sulfur

$\%$ Oxygen (diff.)

\% Mineral Matter

(incl. $4.94 \% \mathrm{FeS}_{2}$ ) dry $\quad \frac{\operatorname{dmmf}(\text { Mod.P) }}{(16.44 \% \text { MM) }}$

$\begin{array}{ll}65.87 & 78.83\end{array}$

$4.47 \quad 5.35$

$1.14 \quad 1.36$

$2.64 \quad 3.16$

$9.44 \quad 11.29$

16.44

CALORIFIC VALUE (Gross)

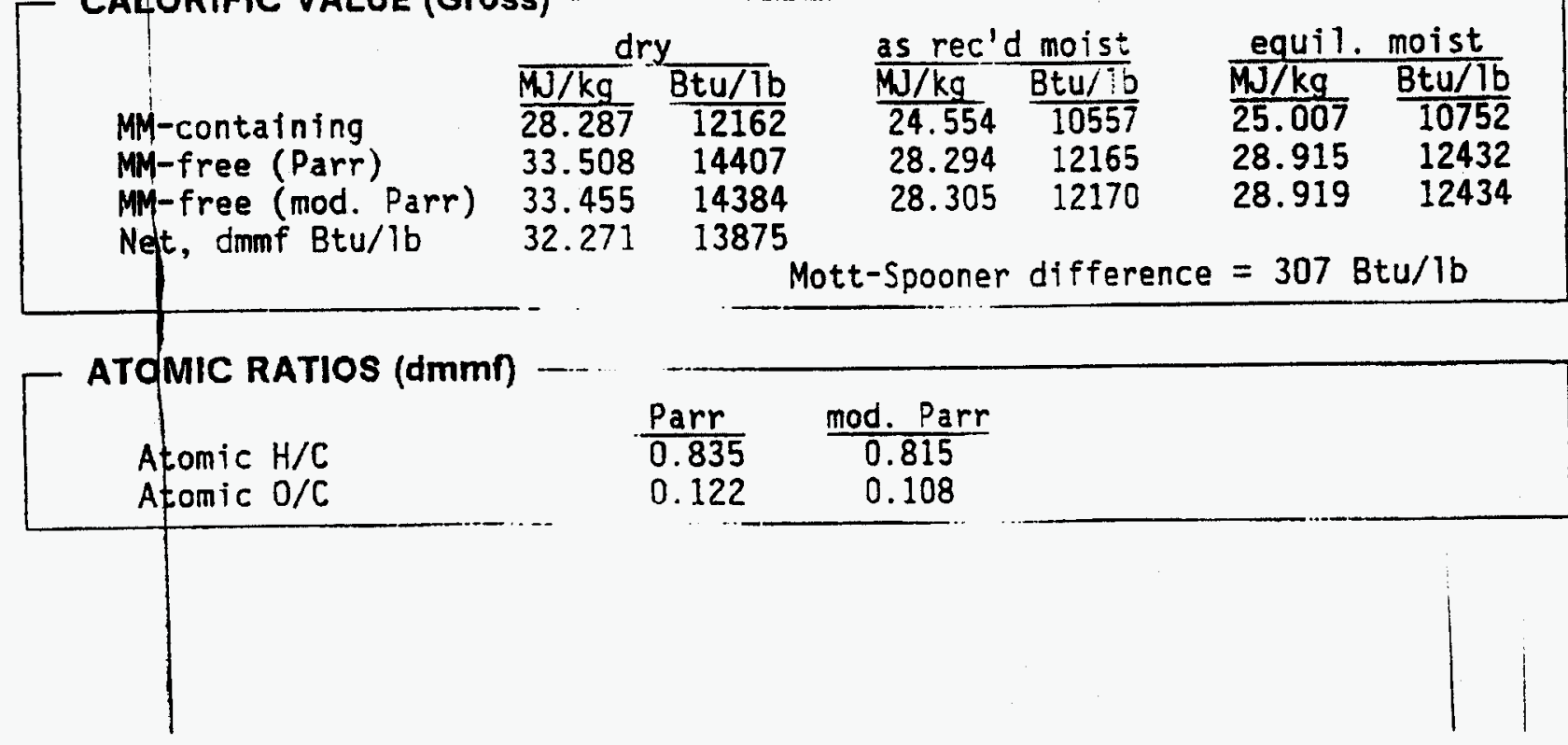




\section{Appendix 2}

Thermogravimtery-Photoionization Mass Spectrometry of Different Rank Coals 
Thermogravimetry-Photoionization Mass Spectrometry Of Different Rank Coals

David L. Zoller and Murray V. Johnston*

Department of Chemistry and Biochemistry

University of Delaware

Newark, DE 19716

Jasna Tomic, Xiaogong Wang, and William H. Calkins*

Deparment of Chemical Engineering

University of Delaware

Newark, DE 19716

*Authors to whom correspondence may be addressed

Submitted to: Energy and Fuels

Submitted: April 16, 1999

Revised: June 11, 1999 


\section{Abstract}

Volatile matter evolved during pyrolysis of 20 different rank coals was studied by by thermogravimetry-photoionization mass spectrometry (TG-PI-MS). The composition of the TGA effluent revealed several significant trends with coal rank. First, the relative intensities of peaks due to compounds containing oxygen such as $\mathrm{C}_{n} \mathrm{H}_{2 n} \mathrm{O}(n=2.3$ or 4$)$. phenols and dihydroxybenzenes decreased with increasing coal rank. Also, the relative intensities of peaks due to aromatic compounds such as naphthalenes, phenanthrenes and pyrenes increased with increasing coal rank. Mass signals due to sulfur compounds evolved from coal showed qualitative correlations berween $\mathrm{CS}_{2}(\% \mathrm{TIC})$ and pyritic sulfur content and between $\mathrm{CH}_{3} \mathrm{SH}(\% \mathrm{TIC})$ and aliphatic sulfur content. Several of the coals were extracted with a solvent to remove the soluble portion of the coal. TG-PI-MS analysis of the raw coal, extracted material and coal residue remaining after solvent extraction produced very similar mass spectra. While the majority of the compounds observed by TG-PI-MS are products of thermal cleavage of bonds within the coal structure, specific compounds or fractions of the coal evolved as thermal desorption products at temperatures lower than the bulk of the volatile matter. This conclusion is further supported by $337 \mathrm{~nm}$ laser desorption mass spectrometry of the solvent extracts. The results from these analyses suggest that volatile matter, like coal itself, consists of compounds with a range of molecular weights but with similar molecular structures. 


\section{Introduction}

A recent thermogravimetric (TGA) study' has shown for a wide variety of coals that volatile matter $(\mathrm{VM})^{2}$ evolves over a relatively narrow $\left(\sim 100^{\circ} \mathrm{C}\right)$ temperature interval. The derivative (DTG) peak maximum for volatile matter evolution was found to increase systematically with caa! rank. The peak temperature also has a strong correlation with vitrinite reflectance, a key indicator of coal rank. Due to the ease of use and common availability of TGA equipment, this method provides a promising alternative to more laborious vitrinite reflectance and rock-eval methods for estimating coal rank. Although the correlation between the DTG peak maximum and coal rank is clear, the compositions and relative amounts of volatile matter evoived and their correlation with the overall coal structure have not been determined. Therefore, in this work, the composition of the volatile matter evolved during thermogravimetric analysis of coals was determined using a photoionization mass spectrometer.

Mass spectrometry is a useful method for identification of products evolved during pyrolysis of coal. The main advantage of mass spectrometry is the ability to rapidly identify a compound (by mass) from a complex distribution of evolved products. A number of mass spectroscopic (MS) methods on coals and coal derived products have been reported in the literature such as high resolution mass spectrometry, ${ }^{3}$ pyrolysis electron-ionization (EI) mass spectrometry ${ }^{4,5}$ and pyrolysis fieid-ionization mass spectrometry. ${ }^{6-9}$ In addition. thermogravimetry has been used in combination with low voltage EI-MS ${ }^{10.11}$ to study the devolatilization and thermal degradation of coals.

Photoionization mass spectrometry allows for rapid and reproducible identification of compounds in the TGA effluent (TG-PI-MS). This method employs 
vacuum ultraviolet (VUV) radiation to "softly" ionize the evolved compounds with minimal fragmentation. Since the photon energy $(10.49 \mathrm{eV})$ is just above the ionization potentials for the majority of the compounds analyzed. fragmentation due to the ionization process is minimized producing primarily molecular ions $\left(\mathrm{M}^{+\bullet}\right)$. The major compound classes which generally do not yield intense molecular ions with $10.49 \mathrm{eV}$ photoionization are aliphatic alcohols, aldehydes and esters. ${ }^{12.13}$ This photoionization method has been previously used to obtain microstructural information for synthetic polymers from their thermal degradation products ${ }^{14,15}$ and to characterize large alkyl radicals produced by photodissociation. ${ }^{16}$ In addition, the open source design of the photoionization mass spectrometer is advantageous for high gas load analysis since the carrier gas $(\mathrm{He})$ and contaminants from the atmosphere (e.g., $\mathrm{N}_{2}, \mathrm{CO} . \mathrm{CO}_{2}, \mathrm{O}_{2}$ ) are not detected because their ionization potentials are above $10.49 \mathrm{eV}$. Also. contamination of the photoionization source is less problematic than with an electron-ionization source because the metal surfaces are held at ambient temperatures and are outside the ionization region. Therefore, numerous coal samples may be analyzed over an extended period of time ( 1 mo.) without requiring cleaning of the ion source or transfer line.

This paper reports on the composition of the volatile matter evolved from coal and how this composition varies with coal rank. For several coais. changes in the TG-PI mass spectra resulting from extraction of the soluble matter from the coal were determined by analysis of the raw coal, the coal after solvent extraction and the extracted material. This technique was able to provide valuable insight into the structures of the more thermally labile components of coal. 


\section{Experimental}

Coal Samples. Twenty coal samples which included 7 Argonne Premium Coals, 10 Department of Energy Coal Samples (DECS from the Penn State Sample Bank) and 3 high sulfur coals (Raša, Charming Creek and Mequinenza) were analyzed by TG-PI-MS. Prior to analysis, all of the coal samples were stored in air-tight containers under a nitrogen atmosphere. The high sulfur coals were chosen to provide additional information on sulfur in coal and the sulfur compounds that are released during thermal decomposition of organic and pyritic sulfur. Analytical data on the coals used in this study ${ }^{17-21}$ are listed in Table 1. Within each group. the coals are listed in order of increasing rank.

Thermogravimetry-Photoionization Mass Spectrometrv. For each analysis, approximately $40 \mathrm{mg}$ of coal was placed in an alumina pan which was loaded into a thermogravimetric analyzer (TGA 2050, TA Instruments, New Castle, DE). Helium flow through the TGA was maintained at $75 \mathrm{~mL} / \mathrm{min}$. The volume of the furnace and transfer line was $35 \mathrm{~mL}$ which gives an average transfer time from the TGA to the mass spectrometer of $14 \mathrm{~s}$. The sample was equilibrated in the TGA furnace at $35^{\circ} \mathrm{C}$ for 10 minutes. A linear temperature program of $20^{\circ} \mathrm{C} / \mathrm{min}$ was then used to heat the sample to a final temperature of $900^{\circ} \mathrm{C}$ and held for $10 \mathrm{~min}$. The gas flow was then changed to air and maintained at $900^{\circ} \mathrm{C}$ for $10 \mathrm{~min}$. Evolved species were transferred from the TGA furnace, through a $50 \mathrm{~cm}$ long, 1/4" O.D. stainless steel tube to a gas split. At the gas split, $2 \mathrm{~mL} / \mathrm{min}$ of the gas was transferred through a $25 \mathrm{~cm}, 100 \mu \mathrm{m}$ diameter, fused silica capillary to the source of the mass spectrometer. The remaining gas flow was sent to an 
atmospheric pressure vent. The transfer lines were maintained at $250^{\circ} \mathrm{C}$ using heating cords.

A reflectron time-of-flight (RETOF) mass spectrometer (R.M. Jordan Co., Grass Valley, CA) was used to detect the evolved molecules. As the coal sample was heated in the TGA, evolved species were transferred into the source of the mass spectrometer and photoionized. Photoionization was performed with radiation derived from the third harmonic of an Infinity 40-100 Nd:YAG laser (Coherent Inc., Santa Clara, CA). Radiation at $355 \mathrm{~nm}$ was frequency tripled in a phase-matched mixture of xenon and argon to yield vacuum ultraviolet (VUV) radiation at $118.2 \mathrm{~nm}(10.49 \mathrm{eV})$. Additional experimental details concerning VUV generation are discussed elsewhere. ${ }^{.2}$ Individual mass spectra were recorded at $50 \mathrm{~Hz}$ with a $500 \mathrm{MHz}$ transient digitizer (Model 9846 . Precision Instruments, Knoxville, TN) mounted in a personal computer. Each recorded mass spectrum was the average of 512 individual mass spectra recorded over a $3.5^{\circ} \mathrm{C}$ temperature interval. Many of these coals were also analyzed using a heated probe inserted directly into the source of the mass spectrometer. Under the vacuum of the mass spectrometer. the total ion currents were very low at room temperature and began to increase only when the samples were heated above $150^{\circ} \mathrm{C}$.

Laser Desorption/Ionization Mass Spectrometry. A linear time-of-flight mass spectrometer (Voyager DE, Perseptive Biosystems, Framingham. MA) was used for 337 $\mathrm{nm}$ laser desorption experiments. A $1 \mu \mathrm{L}$ drop of the pyridine or tetrahydrofuran (THF) extract was placed on a gold-plated sample holder and the solvent was allowed to volatilize in a fume hood. The sample plate was then inserted into the mass spectrometer and laser desorption was performed using $337 \mathrm{~nm}$ radiation from a nitrogen laser. The 
mass spectrometer was operated in positive ion mode with a total acceleration voltage of $20 \mathrm{kV}$.

Solvent Extraction. Selected coals were extracted with a solvent and both the extract and residue were analyzed by TG-PI-MS. Approximately $4 \mathrm{~g}$ of coal was placed in a cellulose thimble and extracted with 50 rat of THF or pyridine in a soxhlet apparatus for $72 \mathrm{~h}$ under a nitrogen atmosphere. The extract was filtered and the solvent was removed by rotary evaporation under a vacuum. The extracts and solid residues were dried under vacuum at $60^{\circ} \mathrm{C}$ for $24 \mathrm{~h}$. The extractable yields with the two solvents were within $5 \mathrm{wt}$ $\%$ daf (dry-ash-free basis) of the values reported in the literature. $: 2 .=4$

Spiking of Coal Samples. In order to determine whether the compounds detected by TGPI-MS are produced by thermal desorption or by thermal cleavage of bonds within the coal structure, two samples of coal were spiked with compounds known to be evolved upon pyrolysis of coals; 1 -phenyltridecane and p-cresol (Aldrich). Wyodak and Pittsburgh \#8 coal $(1 \mathrm{~g})$ were each mixed in a closed container with $1-2 \mathrm{~g}$ of either $p$ cresol or 1-phenyltridecane in $20 \mathrm{~mL}$ of dichloromethane for $48 \mathrm{~h}$. The mixture was then filtered and any excess solvent was removed by distillation. The coal sample was then dried in a vacuum for $24 \mathrm{~h}$ at $60^{\circ} \mathrm{C}$ and analyzed by TG-PI-MS.

\section{Results and Discussion}

Thermogravimetry of Different Rank Coals. Thermogravimetric analysis was performed using the method previously developed for correlating the derivative TGA scan (DTG) with coal rank. ${ }^{\prime}$ However, the heating rate was changed from $10^{\circ} \mathrm{C} / \mathrm{min}$ to $20^{\circ} \mathrm{C} / \mathrm{min}$ in order to decrease analysis time and increase analyte signal. Figure 1 shows a typical TGA scan for Illinois $\# 6$ coal, a high volatile bituminous coal. Three main stages of 
weight loss occur during the TGA analysis. First, moisture is evolved from the coal with a $T_{\text {MAX }}$ of $66.0^{\circ} \mathrm{C}$ resulting in a $3.1 \%$ weight loss for this sample. In the next step, volatile matter is released from the macromolecular coal network resulting in a weight loss of $35.6 \%$. This stage includes all weight loss from the coal sample between 200 $900^{\circ} \mathrm{C}$ under an inert (He) atmosphere with the majority of weight loss occurring between $390-550^{\circ} \mathrm{C}$. For the experimental conditions used in this study, three peaks are observed in the DTG for Illinois $\# 6$ between $200-900{ }^{\circ} \mathrm{C}$. The first peak at $448.8{ }^{\circ} \mathrm{C}$ corresponds to thermal cleavage of bonds within the macromolecular network of coal and thermal desorption of lower molecular weight compounds from coal. A smaller peak at $560.0^{\circ} \mathrm{C}$ is due to thermal degradation of pyritic sulfur in the coal..$^{25}$ Ammonia is detected by TGPI-MS during the third weight loss at $728.6^{\circ} \mathrm{C}$ possibly due to thermal degradation of heterocyclic or quarternary nitrogen compounds. ${ }^{26}$ After $10 \mathrm{~min}$ at $900^{\circ} \mathrm{C}$. the TGA atmosphere is switched from helium to air and the remainder of the coal sample, referred to as fixed carbon ( $\mathrm{FC}$ ), is combusted to $\mathrm{CO}_{2}$ leaving $14.9 \%$ of the original coal mass as ash.

TG-PI Mass Spectra for Different Rank Coals. Compounds evolved as volatile matter from the Argonne and DECS coals were identified by photoionization mass spectrometry. The types and amounts of evolved products varied between coals of different rank and included a wide range of compounds up to $400 \mathrm{~m} / \mathrm{z}$. Compounds above $400 \mathrm{~m} / \mathrm{z}$ are observed by photoionization mass spectrometry although the detection efficiency is generally lower for these compounds. ${ }^{14.15}$ Table 2 list the coals in order of increasing coal rank and the percentage of the total ion current (\% TIC) for several series of 
compounds. It is important to note that these values reflect the relative amounts of compounds evolved between $200-900^{\circ} \mathrm{C}$.

Figure 2 shows the photoionization mass spectra at the derivative peak maxima for volatile matter evolution for each of three different rank coals in the low mass region $(0-200 \mathrm{~m} / \mathrm{z})$. The photoionization due to an alkene series $(\mathrm{m} / \mathrm{z}=42,56,70,84)$. Methane and ethylene $(\mathrm{m} / \mathrm{z}=16,28)$ are not detected because their ionization potentials are above $10.49 \mathrm{eV}$. No significant trend for the alkene series with coal rank is identified in Table 2. Figure 2a shows the photoionization mass spectrum for Wyodak. a lower rank subbituminous coal. at $447^{\circ} \mathrm{C}$. The mass spectrum for Wyodak contains an intense series of peaks due to oxygencontaining compounds such as $\mathrm{C}_{n} \mathrm{H}_{2 n} \mathrm{O}(\mathrm{m} / \mathrm{z}=44,58,72)$, phenols ( $\left.\mathrm{m} / \mathrm{z}=94,108.122\right)$ and dihydroxybenzenes $(\mathrm{m} / \mathrm{z}=110,124,136)$. Compounds with a molecular formula of $\mathrm{C}_{n} \mathrm{H}_{2 n} \mathrm{O}(n=2,3$ or 4$)$ include alkenols, aldehydes and ketones. Based on previous photoionization studies which show significant fragmentation of alkenols and aldehydes, ${ }^{12,13}$ the most probable molecular structures for this series are compounds containing a ketone functional group. Table 2 shows that the $\%$ TIC of the $\mathrm{C}_{n} \mathrm{H}_{2 n} \mathrm{O}$. phenols and dihydroxybenzenes (DHBs) generally decrease with increasing coal rank. Figure $2 \mathrm{~b}$ shows the photoionization mass spectrum for Pittsburgh $\# 8$, a high volatile bituminous coal, at $478^{\circ} \mathrm{C}$. A marked decrease in the relative intensity of peaks due to the $\mathrm{C}_{n} \mathrm{H}_{2 n} \mathrm{O}$ series and a shift in the phenol series toward a higher degree of methylation (i.e.. $\mathrm{m} / \mathrm{z} 122$ and 136 are more intense) is observed. Figure $2 \mathrm{c}$ shows the photoionization mass spectrum for Pocahontas \#3, a higher rank (IVb) coal. at $526^{\circ} \mathrm{C}$. A significant increase in the relative intensities of peaks due to the benzene series $(\mathrm{m} / \mathrm{z}=$ 
$78.92,106,120)$ and the naphthalene series $(\mathrm{m} / \mathrm{z}=128.142,156,170)$ is observed. The mass spectrum for Pocahontas \#3 also contains a marked decrease in the intensity of peaks due to phenols compared to the lower rank coals. As shown in Table 2, the relative amount of benzenes is particularly high for Pocahontas \#3. However, the absolute amount of benzenes evolved is not signifitiatiity giviter for this coal compared to lower rank coals because the total ion current for Pocahontas \#3 is 2-3 times less than the total ion current for the lower rank coals. No significant trend with coal rank is identified for the benzenes. However, the \% TIC for the naphthalenes increases steadily with increasing coal rank. The changes identified in the composition of the TGA effluent are consistent with the overall decrease in oxygen content of the coal with increasing rank (Table 1).

Figure 3 shows that peaks are generally observed at each nominal mass in the high $\mathrm{m} / \mathrm{z}$ region $(200-400 \mathrm{~m} / \mathrm{z})$ of each coal mass spectrum. As with field ionization. ${ }^{4}$ each of these peaks may constitute up to 5 or more compounds with different molecular structures. The contributions to odd mass peaks are primarily ${ }^{13} \mathrm{C}$ isotopes and compounds containing an odd number of nitrogen atoms. Compound classes are assigned based on structures proposed in the mass spectrometry literature for these coals. $^{4-7}$ The most intense series of peaks in the high $\mathrm{m} / \mathrm{z}$ region of the mass spectrum vary greatly with the particular coal analyzed. Figure 3 a shows that the mass spectrum for Wyodak. a subbituminous coal, contains an intense series of peaks at $\mathrm{m} / \mathrm{z}=212,226$. 240 and 254 which corresponds to $C_{3}-C_{6}$ hydroxyacenaphthenes and $C_{1}-C_{4}$ hydroxyfluorenes. Two groups of peaks are also observed at $\mathrm{m} / \mathrm{z}=350$ and 378 and $\mathrm{m} / \mathrm{z}$ $=368$ and 396 for Wyodak and are assigned to $C_{24}$ and $C_{26}$ fatty acids. The peaks at $\mathrm{m} / \mathrm{z}$ 
$=350$ and 378 were not previously observed by direct probe-mass spectrometry ${ }^{4-7}$ and most likely correspond to thermal decomposition of the fatty acids within the TGA furnace. Figure $3 b$ shows the mass spectrum for Pittsburgh $\# 8$ contains an intense series of peaks at $\mathrm{m} / \mathrm{z}=210,224.238$ and 252 which are assigned to a homologous series of acenaphthalenes and biphenyls. Figure $3 \mathrm{c}$ shows the mass spectrum for Pocahontas. a low volatile bituminous coal. contains intense series of peaks at $m / z=230,244$ and 258 attributed to $C_{2}-C_{4}$ pyrenes. Also, a series of peaks at $m / z=266,280$ and 294 identified for Pocahontas coal is attributed to $C_{1}-C_{3}$ perylene or benzopyrene. Table 2 shows the $\%$ TIC for naphthalenes $(\mathrm{m} / \mathrm{z}=128,142.156 .170)$, phenanthrenes $(\mathrm{m} / \mathrm{z}=178,192,206$, $220)$ and pyrenes $(\mathrm{m} / \mathrm{z}=202.216 .230,244)$ increase with increasing coal rank.

Overall, TG-PI-MS analysis shows a trend toward evolved products containing less oxygen and greater aromaticity with increasing coal rank. This trend agrees with NMR analyses of coals ${ }^{27}$ which indicate an increase in aromaticity (aromatic $\mathrm{C}$ and aromatic $\mathrm{C}-\mathrm{H}$ ) with increasing rank and a decrease in oxygen structures (carbonyl $\mathrm{C}$, aromatic C-O, aliphatic $\mathrm{C}-\mathrm{O}$ ).

A partial least-squares model was used to more quantitatively determine the correlation between the photoionization mass spectra and vitrinite reflectance, a key indicator of coal rank. For each coal sample, the ion current at each $\mathrm{m} / \mathrm{z}$ value was summed and then normalized to the total ion current for all of the $\mathrm{m} / \mathrm{z}$ values detected during TG-PI-MS analysis. The model then determined which $m / z$ values and combinations of $\mathrm{m} / \mathrm{z}$ values provided the best correlation with a specific coal property. Based on a leave-one-out cross-validation, a good correlation $\left(R^{2}=0.897\right)$ was determined between the photoionization mass spectra and vitrinite reflectance. The 
important $\mathrm{m} / \mathrm{z}$ values in developing the correlation with vitrinite reflectance were identified by the regression coefficients generated from the partial least-squares model. Similar to our qualitative analysis of the photoionization mass spectra. oxygen-containing compounds such as $\mathrm{C}_{n} \mathrm{H}_{2 n} \mathrm{O}(\mathrm{m} / \mathrm{z}=44,58,72)$ and napthols $(\mathrm{m} / \mathrm{z}=144,158.172)$ have an inverse correlation with vitrinite reflectance (coal rank). Also, aromatic hydrocarbons such as the methylnaphthalenes $(\mathrm{m} / \mathrm{z}=142,156,170)$ and $C_{2}-C_{3}$ benzenes $(\mathrm{m} / \mathrm{z}=106$, 120) have a strong positive correlation with vitrinite reflectance.

Sulfur Species Detected by TG-PI-MS. The primary sulfur compounds evolved during the thermogravimetric analyses of different rank coals are $\mathrm{H}_{2} \mathrm{~S}, \mathrm{CH}_{3} \mathrm{SH} . \mathrm{S}_{2}, \mathrm{CS}_{2}$ and thiophenic compounds. In previous work, ${ }^{28.29} \mathrm{SO}_{2}$ and $\mathrm{COS}$ were detected using high resolution (EI) mass spectrometry. However, in this study, $\mathrm{SO}_{2}$ and $\mathrm{COS}$ were not detected by the photoionization mass spectrometer because their ionization potentials are above $10.49 \mathrm{eV}$. As shown in Figure 1, a weight loss around $560^{\circ} \mathrm{C}$ was observed during thermogravimetric analysis of Illinois $\# 6$ coal. Previous work ${ }^{25}$ has shown that this weight loss corresponds to thermal decomposition of pyritic sulfur in coal. Table 3 shows the pyritic sulfur content for each of the coals analyzed and the suifur compounds evolved from $550-650^{\circ} \mathrm{C}$ as a percentage of the total ion current for each analysis. The percentages for these sulfur compounds are not directly quantitative because the photoionization cross-sections for each species is different. As in previous mass spectrometry studies by Calkins, ${ }^{28} \mathrm{CS}_{2}$ was identified in the photoionization mass spectra around $560^{\circ} \mathrm{C}$ for coals containing a relatively high pyritic sulfur content $(>0.5 \mathrm{wt} \%)$. For many of the high pyritic sulfur coals, $\mathrm{H}_{2} \mathrm{~S}$ and $\mathrm{S}_{2}$ were also observed in the 
photoionization mass spectra at $560^{\circ} \mathrm{C}$. These sulfur compounds may arise from reactions between pyrite and the surrounding coal matrix. ${ }^{30}$

Sulfur compounds associated with organic sulfur in coal, typically $\mathrm{H}_{2} \mathrm{~S}, \mathrm{CH}_{3} \mathrm{SH}$, $S_{2}$ and thiophenic compounds, are evolved in the temperature region of volatile matter degradation $\left(390-550^{\circ} \mathrm{C}\right)$. Table 4 shows the organic sulfur content for each of the coals analyzed and the sulfur compounds evoived during the volatile matter degradation as a percentage of the total ion current for each analysis. For lignite and subbituminous coals with low organic sulfur content $(<1 \mathrm{wt} . \%)$, the most intense sulfur peak in the mass spectrum is $\mathrm{CH}_{3} \mathrm{SH}$. As shown in Table $5, \mathrm{CH}_{3} \mathrm{SH}$ is correlated with aliphatic sulfur content as determined by XANES. ${ }^{21.31}$ Methylmercaptan may be a thermal degradation product resulting from $\alpha$-cleavage of aliphatic sulfur species. In bituminous coals with high organic sulfur content $(>1 \mathrm{wt} . \%), \mathrm{H}_{2} \mathrm{~S}$ and $\mathrm{S}_{2}$ are the dominant thermal degradation products of coals. Also, thiophenic sulfur compounds are detected for these high organic sulfur coals and the most intense peak is due to methylthiophene. Thiophenic compounds have a higher limit of detection than the other sulfur compounds because they have the same nominal mass as an alkene series $(m / z=84.98,112)$. Using our current RETOF mass spectrometer, the mass peaks are not entirely resolved. For bituminous coals with low sulfur contents $(<1 \mathrm{wt} \%)$, few sulfur compounds are evolved during thermogravimetric analysis. In this case, sulfur may be incorporated into the macromolecular network and therefore the small amount of sulfur present may not be evolved at temperatures up to $900^{\circ} \mathrm{C}$.

Solvent Extraction of Coals. Several coals were extracted with THF and/or pyridine to remove the soluble part of the coal and determine its effect on the volatile matter content. 
Table 6 shows that the Illinois \#6 and Pittsburgh $\# 8(\mathrm{hVb})$ coals contained higher amounts of THF extractable material. 19.0 and $16.8 \mathrm{wt} \%$ respectively. Wyodak (sub) and Upper Freeport (mVb) coals contained considerably less extractable material, 9.2 and 5.5 wt $\%$ respectively. The samples were dried in a vacuum oven prior to analysis by TG-PI-MS. However, a significant portion of the soivent remained trapped within the coal. ${ }^{32}$ To correct for varying amounts of residual solvent between different coal samples, the values in Table 6 are reported on a dry basis (excluding moisture and solvent).

For a given coal, the volatile matter content is highest for the extract and lowest for the residue indicating that the solvent extraction removed a portion of the volatile matter originally present in the raw coal. Overall, the decrease in volatile matter content after solvent extraction was rather modest with a maximum decrease of $20 \mathrm{wt} \%$ for Illinois $\# 6$ coal extracted with pyridine. The relative decrease in volatile matter before and after extraction is proportional to the extraction yield. For example, the change is negligible for the Wyodak and Upper Freeport coals which had very low solvent extraction yields. Also, the change in volatile matter is greater for coals extracted with pyridine than for coals extracted with THF.

Figure 4 shows the photoionization mass spectra for the pyridine extract, residue and raw Pittsburgh \#8 coal at the temperature of the DTG maximum for volatile matter (484 ${ }^{\circ} \mathrm{C}$ for this coal). Qualitatively, the composition of the extract, the raw coal and the residue are very similar and the relative intensities of peaks are almost identical for each of the samples. The major differences are due to residual pyridine $(m / z=79)$ and a pyridine dimer $(\mathrm{m} / \mathrm{z}=156)$. A second difference is the higher relative intensity of the 
$\mathrm{H}_{2} \mathrm{~S}$ peak $(\mathrm{m} / \mathrm{z}=34)$ present in the residue presumably due to an increase in nonextractable, inorganic sulfur compounds relative to the volatile matrer.

For several coals, the solvent preferentially extracted specific components or portions of the coal, which evolve at lower temperatures than the rest of the volatile matter. For example, Pittsburgh \#8 coal is known to contain a fraction due to thermally extractable bitumen" ${ }^{96}$ which evolves at slightly lower temperatures than the bulk of the volatile matter. These components are characterized by intense peaks for a methylnaphthalene series $(\mathrm{m} / \mathrm{z}=142,156,170)$ and were observed in the pyridine and THF extracts of Pittsburgh \#8 coal. Figure 5 shows the ion currer: for the $142 \mathrm{~m} / \mathrm{z}$ peak as a function of temperature for the raw coal, pyridine extract and :esidue after pyridine extraction. From Figure 5, it is apparent that the "thermally extraciable bitumen" is extracted by the solvent and that it evolves at much lower temperanures for the extract when compared to the raw coal. Similarly, the long chain fatty acids $(\mathrm{m} / \mathrm{z}=368,396$, 424) in Wyodak coal have been shown to evolve at lower temperatures than the bulk of the volatile matter. ${ }^{4}$ TG-PI-MS analysis of the Wyodak extract showed that these same fatty acids are detected in raw coal and the THF extract but are not present in the residue. Thermal Desorption vs. Bond Cleavage. A question arises as to whether the compounds detected by TG-PI-MS are due to thermal desorption from coal or thermal cleavage of bonds within the coal structure. As stated previously, fatty acids were identified as thermal desorption products from Wyodak coal. However, the majority of the products detected during the evolution of volatile matter were low mass compounds $(<400 \mathrm{~m} / \mathrm{z}$ ). These low mass compounds are typically evolved at temperatures between $400-600^{\circ} \mathrm{C}$ which greatly exceeds the boiling points for many of these compounds. Therefore, the 
compounds detected by TG-PI-MS are believed to be predominantly due to cleavage of bonds in the higher molecular weight and less thermally-stable structures present in coal. This conclusion is further supported by TG-PI-MS analyses of spiked coal samples. A sample of Pittsburgh $\# 8$ coal was spiked with $p$-cresol, a phenolic pyrolysate. A second sample of Pittsburgh \#8 was spiked with 1-phenyltridecane, an alkyl-aromatic pyrolysate. The added p-cresol and 1-phenyltridecane both evolved at lower temperatures than the main volatile matter evolution of the coal. The ion current maximum for the spiked $p$ cresol $(\mathrm{m} / \mathrm{z}=108)$ at $144^{\circ} \mathrm{C}$ is $340^{\circ} \mathrm{C}$ lower than the corresponding maximum at $484{ }^{\circ} \mathrm{C}$ for the raw coal. Similarily, ion current maximum for the spiked 1-phenyltridecane $(\mathrm{m} / \mathrm{z}$ $=260$ ) at $415^{\circ} \mathrm{C}$ is $69^{\circ} \mathrm{C}$ lower than the corresponding maximum at $484^{\circ} \mathrm{C}$ for the raw coal. Therefore, compounds observed in this molecular weight range are most likely due to thermal cleavage of bonds within the coal structure and not thermal desorption of compounds from coal.

Laser desorption mass spectrometry (LD-MS) of the extracts for Pittsburgh \#8 and Illinois \#6 coals also supports the predominance of products due to cleavage of bonds within the coal structure. An intense distribution of peaks between $250-600 \mathrm{~m} / \mathrm{z}$ (not shown here) was observed in the $337 \mathrm{~nm}$ laser desorption mass spectra therefore the coal contains an abundance of high molecular $(>400 \mathrm{~m} / \mathrm{z}$ ) compounds. On the other hand, the distribution of peaks obtained by TG-PI-MS contains a very low relative intensity of products above $300 \mathrm{~m} / \mathrm{z}$ compared to products evolved below $300 \mathrm{~m} / \mathrm{z}$ (see Figures 2 and 3). This implies that the higher molecular weight compounds observed by LD-MS are thermally degraded during TG-PI-:MS experiments and are products of thermal cleavage of bonds within the coal structure. 


\section{Conclusions}

Thermogravimetry-photoionization mass spectrometry (TG-PI-MS) of the volatile matter evolved from a wide variety of coals has revealed several significant trends with coal rank. Overall, the relative amounts of oxygen-containing compounds such as $\mathrm{C}_{n} \mathrm{H}_{2 n} \mathrm{O}$. phenols and dihydroxybenzenes decrease with increasing coal rank. This decrease correlates well with the overall decrease in oxygen content of the coals with increasing rank. In addition, the relative amounts of aromatic hydrocarbons such as naphthalenes, phenanthrenes and pyrenes increase with increasing coal rank. This increase in aromaticity of the evolved products correlates with an overall increase in the aromaticity of the coal. The higher stability of aromatic compounds relative to aliphatic hydrocarbons may contribute to the increase in the temperature of maximum volatile matter evolution with increasing coal rank.

Two separate techniques confirmed that the majority of compounds detected by TG-PI-MS were products of thermal bond cleavages and not thermal desorption products. First. it was determined that compounds spiked in coal evolved at much lower temperanures than the same compounds evolved upon pyrolysis of the raw coal. In addition. laser desorption mass spectrometry of coal extracts revealed a higher molecular weight distribution of compounds than detected by TG-PI-MS. Therefore, these higher molecular weight compounds must pyrolyze in the TGA prior to detection by mass spectrometry.

Some of the volatile matter detected by TG-PI-MS may be removed from coal by solvent extraction with THF or pyridine. Although differences in the absolute amount of compounds evolved from the solvent extract, the coal after extraction and the raw coal 
exist, the relative intensities of compounds detected by photoionization mass spectrometry remain virtually identical. This suggests that the volatile matter consists of a range of molecular weights with similar molecular structures. The lower molecular weight material is more soluble leaving a significant fraction of higher molecular weight volatile matter in the coal after solvent extraction. As shown in Figures 2 and 3, the main thermal degradation products are alkenes, aromatic and hydroxy-aromatic compounds. The evolved products identified by TG-PI-MS suggest the generally postulated structure of the macromolecular network of coal which is believed to contain clusters of aromatic rings separated by aliphatic, thioether and ether bridges. ${ }^{3.34}$

\section{Acknowledgments}

This research was supported in part by the Department of Energy under contract number DE-FG26-97FT97264 (WHC) and in part by NSF Grant number CHE-9629672 (MVJ). The authors wish to thank Dr. Karl Vorres for the Argonne Premium coal samples and David Glick for the Department of Energy coal samples from the Penn State sample bank. The authors would also like to acknowledge Dr. Henk Meuzelaar for his advice on design and operation of the TG-MS equipment. 


\section{References}

1. Huang, H.; Wang, S.; Wang, K.: Klein, M. T.; Calkins. W. H.; Davis, A. Energy and Fuels 1999, 13, 396-400.

2. ASTM Method D3175: defined as the total wt $\%$ loss upon heating of $1 \mathrm{~g}$ of coal at $950 \pm 20^{\circ} \mathrm{C}$ for $10 \mathrm{~min}$ excluding the $\mathrm{wt} \%$ loss due to moisture.

3. Winans, R. E. In Advances in Coal Spectroscopy; Meuzelaar, H. L. C., Ed.; Plenum Press: New York. 1992; pp 255-274.

4. Yun, Y.; Meuzelaar, H. L.; Simmleit, N.; Schulten, H. R. Energy and Fuels 1991, 5, 22-29.

5. Meuzelaar, H. L. C.; Yun. Y.; Chakravarty, T.; Metcalf, G. S. In Advances in Coal Spectroscopy; Meuzelaar. H. L. C., Ed.; Plenum Press: New York, 1992; pp 275294.

6. Simmleit, N.; Schulten. H. R.; Yun. Y.: Meuzelaar, H. L. C. In Advances in Coal Spectroscopy; Meuzelaar. H. L. C., Ed.; Plenum Press: New York, 1992: pp 295339.

7. Marzec, A.; Schulten. H. R. Fuel 1994, 73, 1294-1305.

8. Malhotra, R.; McMillen. D. F. Amer. Chem. Soc. Preprints, Div. Fuel. Chem. 1992, 37, 1214-1220.

9. Malhotra, R.; McMillen. D. F.; Huestis, D. L. Amer. Chem. Soc. Preprints, Div. Fuel Chem. 1991, 36, 1252-1258.

10. Yun, Y.; Meuzelaar, H. L. C. Amer. Chem. Soc. Preprints, Div. Fuel. Chem. 1988, $33,75-85$.

11. Nie, X.; Lui, K.; Maswadeh. W.; Tripathi, A.; Meuzelaar, H. Amer. Chem. Soc. Preprints, Div. Fuel Chem. 1994, 39, 558-563.

12. Van Bramer, S. E.; Johnston, M. V. J. Am. Soc. Mass Spectrom. 1990, 1, 419-426.

13. Van Bramer, S. E.; Johnston, M. V. Appl. Spectrosc. 1992, 46, 255-261.

14. Zoller, D. L.; Johnston. M. V. Anal. Chem. 1997, 69, 3791-3795.

15. Zoller, D. L.; Sum, S. T.: Johnston, M. V.; Qian, K.; Hatfield. G. R. Anal. Chem. 1999, 71, 866-872.

16. Ross, P. L.; Johnston. M. V. J. Phys. Chem. 1995, 99, 16507-16510.

17. Vorres, K. S. In User's Handbook for the Argonne Premium Coal Sample Program; Argonne National Laboratories: Argonne, IL, 1993. 
18. In The Penn State Coal Sample Bank and Database - DECS Series Analytical Data Printouts; Pennsylvania State University: University Park, PA, 1995.

19. White, C. M.; Douglas, L. J.; Anderson. R. R.; Schmidt, C. E. In Geochemistry of Sulfur in Fossil Fuels; Orr, W. L. and White, C. M., Ed.; American Chemical Society: Washington D.C., 1990; pp 261-286.

20. Torres-Ordonez, R. J.; Calkins, W. H.; Klein, M. T. In Geochemistry of Sulfur in Fossil Fuels; Orr, W. L. and White, C. M., Ed.; American Chemical Society: Washington D.C., 1990; pp 475-484.

21. Calkins, W. H. Fuel 1994, 73, 475-484.

22. Van Bramer, S. E.; Johnston, M. V. Appl. Spectrosc. 1992, 46, 255-261.

23. Carlson, R. E.; Critchfield, S.; Vornick, W. P.; Dong, J. Z.; Pugmire. R. J.; Lee, M. L.; Zhang, Y.; Shabtai, J.; Bartle. K. D. Fuel 1992, 71, 19-29.

24. Chang, H. C.; Bartle, K. D.; Markides. K. E.; Lee, M. L. In Advances in Coal Spectroscopy; Meuzelaar. H. L. C., Ed.; Plenum Press: New York. 1992: pp 141164.

25. Maes, I. I.; Yperman, J.; Vandenrul, H.; Franco, D. V.; Mullens. J.; Vanpoucke, L. C.; Gryglewicz, G.; Wilk, P. Energy Fuels 1995, 9, 950-955.

26. Kelemen, S. R.; Gorbaty, M. L.; Kwiatek, P. J. Energy and Fuels 1994, 8. 896-906.

27. Solum, M.; Pugmire, R. J.; Grant, D. M. Energy and Fuels 1989, j. 187-193.

28. Calkins, W. H. Energy and Fuels 1987, 1, 59.

29. Calkins, W. H. Amer. Chem. Soc. Preprints, Div. Fuel Chem. 1985, 30. +50.

30. Gryglewicz, G.; Wilk, P.; Yperman, J.; Franco, D. V.; Maes. I. I.; Mullens, J.; Vanpoucke, L. C. Fuel 1996, 75, 1499-1504.

31. George, G. N.; Gorbaty, M. L.; Kelemen, S. R.; Sansone, M. Energy and Fuels 1991, 5, 93-97.

32. Collins, C. J.; Hagaman, E. W.; Jones, R. M.; Raaen, V. F. Fuel 1981, 60, 359-360.

33. Shinn, J. Fuel 1984, 63, 1187-1195.

34. Faulon, J. L.; Carlson, G. A.; Hatcher, P. G. Energy and Fuels 1993, 7, 1062-1072. 
Table 1. Analytical Data for the Coals Studied

\begin{tabular}{|c|c|c|c|c|c|c|c|c|c|c|}
\hline \multirow[t]{2}{*}{ No. } & \multirow[t]{2}{*}{ Coal } & \multirow[t]{2}{*}{ Rank } & $\mathrm{C}$ & $\mathrm{H}$ & $\mathbf{O}$ & $S_{\text {organic }}$ & $N$ & \multirow{2}{*}{$\begin{array}{c}\begin{array}{c}\text { Volatile } \\
\text { Matter } \\
\text { (wt \% dry) }\end{array} \\
\end{array}$} & \multirow{2}{*}{$\begin{array}{c}\text { Vitrinite } \\
\text { Reflectance } \\
\left(R_{0} \max \%\right)\end{array}$} & \multirow{2}{*}{$\begin{array}{l}\text { Vitrinite } \\
\text { (maf \%) }\end{array}$} \\
\hline & & & \multicolumn{5}{|c|}{ (wt \% daf basis) } & & & \\
\hline & Argonne Premium & & & & & & & & & \\
\hline 1 & Beulah-Zap & lig & 72.94 & 4.83 & 20.34 & 0.70 & 1.15 & 44.9 & 0.25 & 74 \\
\hline 2 & Wyodak-Anderson & subC & 75.01 & 5.35 & 18.02 & 0.47 & 1.12 & 44.7 & 0.32 & 89 \\
\hline 3 & Illinois \#6 & $\mathrm{hVCb}$ & 77.67 & 5.00 & 13.51 & 2.38 & 1.37 & 40.0 & 0.46 & 85 \\
\hline 4 & Pittsburgh \#8 & hVAb & 83.20 & 5.32 & 8.83 & 0.89 & 1.64 & 37.8 & 0.81 & 85 \\
\hline 5 & Lewiston-Stockton & hVAb & 82.58 & 5.25 & 9.83 & 0.65 & 1.56 & 30.2 & 0.89 & 73 \\
\hline 6 & Upper Freeport & $\mathbf{m V b}$ & 85.50 & 4.70 & 7.51 & 0.74 & 1.55 & 27.5 & 1.16 & 92 \\
\hline 7 & $\begin{array}{l}\text { Pocahontas \#3 } \\
\text { Dept. of Encrgy }\end{array}$ & IVb & 91.05 & 4.44 & 2.47 & 0.50 & 1.33 & 18.6 & 1.68 & 89 \\
\hline 8 & DECS-25 & $\operatorname{lig} A$ & 74.60 & 5.22 & 18.30 & 0.40 & 1.07 & 42.0 & 0.23 & $74^{b}$ \\
\hline 9 & DECS-1 & subC & 74.27 & 5.64 & 17.45 & 1.02 & 1.40 & 47.4 & 0.36 & 78 \\
\hline 10 & I)I:(S-9 & subl3 & 75.54 & 5.18 & 17.94 & 0.33 & 0.90 & 44.4 & 0.38 & 88 \\
\hline 11 & DIECS-10 & subl3 & 78.19 & 4.22 & 15.21 & 0.54 & 1.05 & 41.7 & 0.42 & 74 \\
\hline 12 & DECS-27 & subA & 77.84 & 5.34 & 14.71 & 0.51 & 1.28 & 35.7 & 0.46 & 81 \\
\hline 13 & DECS-2 & $\mathrm{hVCb}$ & 78.11 & 5.44 & 9.73 & 2.67 & 1.32 & 38.1 & 0.52 & 87 \\
\hline 14 & DECS-18 & hVBb & 79.08 & 5.8 & 8.89 & 2.09 & 1.44 & 41.2 & 0.56 & 86 \\
\hline 15 & DECS-22 & hVAb & 84.57 & 5.84 & 5.59 & 0.69 & 1.77 & 30.5 & 0.77 & 30 \\
\hline 16 & DECS-12 & hVAb & 83.32 & 5.69 & 8.37 & 0.81 & 1.37 & 36.0 & 0.87 & 83 \\
\hline 17 & $\begin{array}{l}\text { DECS-3 } \\
\text { High Sulfur }\end{array}$ & $\mathrm{mVb}$ & 87.37 & 5.88 & 4.32 & 0.57 & 1.74 & 27.2 & 1.28 & 94 \\
\hline 18 & Mequinenza & lig & 68.55 & 5.37 & 12.56 & 11.80 & 0.91 & 43.3 & 0.35 & $68^{b}$ \\
\hline 19 & Charming Creek & - & 78.57 & 5.35 & 9.33 & 5.62 & 1.05 & - & - & - \\
\hline 20 & Raša & - & 80.23 & 5.21 & 1.54 & 11.44 & 1.23 & 52.5 & 0.68 & 90 \\
\hline
\end{tabular}

See refs. 15-19

b huminite 
Table 2. Relative Amounts of Different Compound Classes (\% Total Ion Current) Evolved During Pyrolysis of Different Rank Coals (200)-900 ${ }^{\circ} \mathrm{C}$ ).

\begin{tabular}{|c|c|c|c|c|c|c|c|c|}
\hline Coal & Alkenes & $\mathrm{C}_{n} \mathrm{H}_{2 n} \mathrm{O}^{n}$ & Benzenes & Phenols & $\mathrm{DHBs}^{\mathrm{b}}$ & Naphthalenes & Phenanthrenes & Pyrenes \\
\hline DECS-25. & 13.1 & 4.7 & 12.2 & 25.1 & 4.0 & 3.4 & 1.1 & 0.3 \\
\hline Bculah-7ap & 13.6 & 5.9 & 13.1 & 27.7 & 4.2 & 4.0 & 0.7 & 0.0 \\
\hline Wyoxlak & 13.1 & 4.1 & 11.0 & 25.3 & 4.5 & 4.0 & 1.0 & 0.3 \\
\hline DECS-1 & 15.1 & 3.6 & 9.3 & 14.1 & 3.9 & 3.7 & 1.6 & 0.7 \\
\hline DECS-9 & 13.5 & 3.7 & 9.9 & 22.1 & 6.2 & 3.4 & 1.4 & 0.4 \\
\hline DECS-10 & 16.1 & 2.7 & 11.6 & 22.2 & 4.2 & 4.0 & 1.3 & 0.4 \\
\hline DECS-27 & 14.8 & 2.2 & 12.2 & 23.5 & 4.1 & 4.9 & 1.2 & 0.4 \\
\hline Illinois \#6 & 13.5 & 3.7 & 9.9 & 22.1 & 6.2 & 3.4 & 1.4 & 0.4 \\
\hline DECS-2 & 10.2 & 1.2 & 7.2 & 22.7 & 6.2 & 3.1 & 2.4 & 0.9 \\
\hline DECS-18 & 9.8 & 0.9 & 5.1 & 19.6 & 6.2 & 3.2 & 2.4 & 1.2 \\
\hline DECS-22 & 19.3 & 1.2 & 8.5 & 11.0 & 2.2 & 3.9 & 2.5 & 1.5 \\
\hline Pittsburgh \#8 & 11.2 & 0.9 & 8.2 & 15.5 & 2.8 & j.9 & 2.9 & 1.5 \\
\hline DECS-12 & 10.7 & 0.7 & 7.0 & 18.6 & 3.5 & 4.9 & 2.4 & 1.4 \\
\hline Lewiston-Stockton & 14.5 & 0.9 & 11.4 & 18.1 & 2.6 & 5.6 & 2.2 & 1.0 \\
\hline Upper Freeport & 15.1 & 0.2 & 13.9 & 11.3 & 1.6 & 8.4 & 3.5 & 1.9 \\
\hline DECS-3 & 20.3 & 0.6 & 11.3 & 8.2 & 2.1 & 8.1 & 3.1 & 1.7 \\
\hline Pocahontas \#3 & 16.5 & 0.7 & 25.4 & 9.3 & 0.8 & 10.0 & 2.3 & 1.9 \\
\hline
\end{tabular}

"either an aldehyde, ketone or alkenol structure $(n=2,3$ or 4$)$

b dihydroxybenzenes 
Table 3. Sulfur Compounds Evolved During Pyrolysis of Pyritic Sulfur in Coals $\left(550-650^{\circ} \mathrm{C}\right)^{\mathrm{a}}$

\begin{tabular}{|c|c|c|c|c|}
\hline Coal & $\begin{array}{l}S_{\text {pyritic }} \\
\text { (wt \%) }\end{array}$ & $\begin{array}{c}\mathrm{CS}_{2} \\
(\% \text { TIC })\end{array}$ & $\begin{array}{c}\mathrm{H}_{2} \mathrm{~S} \\
(\% \text { TIC }) \\
\end{array}$ & $\begin{array}{c}S_{2} \\
(\% \text { TIC })\end{array}$ \\
\hline Charming Creek & 0.09 & 0.11 & - & 1.41 \\
\hline DECS-9 & 0.10 & 0.05 & - & - \\
\hline DECS-3 & 0.11 & - & - & - \\
\hline DECS-1 & 0.13 & 0.14 & - & - \\
\hline Beulah-Zap & 0.17 & 0.25 & 0.97 & 3.24 \\
\hline Pocahontas & 0.18 & 0.09 & - & - \\
\hline Lewiston-Stockton & 0.19 & - & - & - \\
\hline Wyodak & 0.20 & 0.09 & 0.04 & - \\
\hline DECS-27 & 0.28 & 0.16 & - & - \\
\hline Raša & 0.35 & 0.69 & - & 1.59 \\
\hline DECS-12 & 0.39 & 0.14 & 0.06 & - \\
\hline DECS-10 & 0.69 & 0.63 & 0.08 & 0.28 \\
\hline DECS-22 & 1.18 & 0.99 & - & 1.06 \\
\hline Mequinenza & 1.32 & 1.37 & 8.00 & 18.44 \\
\hline Pittsburgh \#8 & 1.38 & 0.07 & - & - \\
\hline Upper Freeport & 1.78 & 0.17 & - & - \\
\hline DECS-2 & 2.28 & 1.27 & - & - \\
\hline DECS-18 & 2.38 & 1.92 & 8.32 & 4.45 \\
\hline Illinois \#6 & 2.82 & 1.52 & 32.18 & 24.18 \\
\hline
\end{tabular}


Table 4. Sulfur Compounds Evolved During Pyrolysis of Organic Sulfur in Coals $\left(200-550^{\circ} \mathrm{C}\right)^{\mathrm{a}}$

\begin{tabular}{lcccccc}
\hline Coal & $\begin{array}{c}\mathrm{S}_{\text {organic }} \\
\text { (wt \% daf) }\end{array}$ & Rank & $\begin{array}{c}\mathrm{H}_{2} \mathrm{~S} \\
(\% \mathrm{TIC})\end{array}$ & $\begin{array}{c}\mathrm{CH}_{3} \mathrm{SH} \\
(\% \mathrm{TIC})\end{array}$ & $\begin{array}{c}\mathrm{S}_{2} \\
(\% \mathrm{TIC})\end{array}$ & $\begin{array}{c}\mathrm{CH}_{3}-\mathrm{Th}^{\mathrm{a}} \\
(\% \mathrm{TIC})\end{array}$ \\
\hline DECS-9 & 0.33 & subB & 0.06 & 0.61 & 0.05 & - \\
DECS-25 & 0.40 & ligA & 0.06 & 0.93 & 0.05 & - \\
Wyodak & 0.47 & subC & 0.18 & 1.06 & - & - \\
Pocahontas & 0.50 & $\mathrm{lVb}$ & - & - & - & - \\
DECS-27 & 0.51 & subA & 0.10 & - & - & - \\
DECS-10 & 0.54 & subB & - & 0.29 & 0.06 & - \\
DECS-3 & 0.57 & $\mathrm{mVb}$ & - & - & - & - \\
Lewiston-Stockton & 0.65 & hVbA & - & - & - & - \\
DECS-22 & 0.69 & hVbA & 0.10 & 0.02 & - & - \\
Beulah-Zap & 0.70 & lig & 1.12 & 1.98 & 1.18 & - \\
Upper Freeport & 0.74 & $\mathrm{mVb}$ & - & - & - & - \\
DECS-12 & 0.81 & hVbA & 0.11 & 0.03 & 0.02 & - \\
Pittsburgh \#8 & 0.89 & hVbA & 0.97 & 0.15 & 0.01 & - \\
DECS-1 & 1.02 & subC & 0.33 & 1.21 & 0.11 & 0.42 \\
DECS-18 & 2.09 & hVbB & 9.03 & 1.76 & 0.96 & 0.64 \\
Illinois \#6 & 2.38 & hVbC & 9.54 & 1.69 & 4.90 & 0.83 \\
DECS-2 & 2.67 & hVbC & 7.93 & 2.72 & 2.13 & 0.88 \\
Charming Creek & 5.62 & na & 15.17 & 0.58 & 2.05 & 0.41 \\
Raša & 11.44 & na & 9.85 & 1.31 & - & 0.61 \\
Mequinenza & 11.80 & lig & 16.30 & 2.31 & 6.32 & 1.84 \\
\hline TAbbrat
\end{tabular}

Abbreviations: $\mathrm{CH}_{3}-\mathrm{Th}=$ methyl-thiophen: . - not detectable, na = not available. TIC = total ion current 
Table 5. Correlation between Aliphatic Sulfur Content and Methylmercaptan ${ }^{a}$

\begin{tabular}{|c|c|c|}
\hline Coal & $\begin{array}{c}\text { Aliphatic } \mathrm{S}^{\circ} \\
\left(\mathrm{mol} \% \mathrm{~S}_{\text {omenic }}\right.\end{array}$ & $\begin{array}{l}\mathrm{CH}_{3} \mathrm{SH} \\
(\% \mathrm{TIC})\end{array}$ \\
\hline Mequinenzza & 48 & 2.31 \\
\hline Beulah-Zap & 35 & 1.98 \\
\hline Illinois \#6 & 33 & 1.69 \\
\hline Wyodak & 33 & 1.06 \\
\hline Rasa & 30 & 1.31 \\
\hline Charming Creek & 28 & 0.58 \\
\hline Pittsburgh $\# 8$ & 22 & 0.15 \\
\hline Lewiston-Stockton & 19 & - \\
\hline Pocahontas & 13 & - \\
\hline Upper Freeport & 13 & - \\
\hline
\end{tabular}


Table 6. Different Stages of TGA Weight Loss for the Extracted Coals

\begin{tabular}{|c|c|c|c|c|}
\hline Coal Sample & $\begin{array}{l}\text { Extracted } \\
\text { (wt \% daf) } \\
\end{array}$ & $\begin{array}{c}\text { Volatiie } \\
\text { Matter (VM) } \\
\text { (wt \%. dry) }\end{array}$ & $\begin{array}{c}\text { Fixed Carion } \\
\& \text { Ash (FCA }) \\
\text { (wt \%. dry) }\end{array}$ & VM:FCA \\
\hline \multicolumn{5}{|l|}{ Illinois \#6 } \\
\hline Pyridine Extract & 25.3 & 35.0 & 65.0 & 0.55 \\
\hline Raw Coal & & 32.8 & 67.2 & 0.49 \\
\hline Pyridine Residue & & 28.7 & 71.3 & 0.40 \\
\hline THF Extract & 19.0 & 45.0 & 55.0 & 0.82 \\
\hline Raw Coal & & 32.8 & 67.2 & 0.49 \\
\hline THF Residue & & 30.6 & 69.4 & 0.44 \\
\hline \multicolumn{5}{|l|}{ Pittsburgh \#8 } \\
\hline Pyridine Extract & 28.6 & 38.1 & 61.9 & 0.62 \\
\hline Raw Coal & & 32.5 & 67.5 & 0.48 \\
\hline Pyridine Residue & & 26.7 & 73.3 & 0.36 \\
\hline THF Extract & 16.8 & 41.4 & 58.6 & 0.71 \\
\hline Raw Coal & & 32.5 & 67.5 & 0.48 \\
\hline THF Residue & & 28.2 & 71.8 & 0.39 \\
\hline \multicolumn{5}{|l|}{ Wyodak } \\
\hline$\overline{\text { THF Extract }}$ & 9.2 & 64.0 & 36.0 & 1.78 \\
\hline Raw Coal & & 38.7 & 61.2 & 0.63 \\
\hline THF Residue & & 38.9 & 61.1 & 0.64 \\
\hline \multicolumn{5}{|l|}{ Upper Freeport } \\
\hline THF Extract & 5.5 & 46.6 & 53.4 & 0.87 \\
\hline Raw Coal & & 23.9 & 76.1 & 0.31 \\
\hline THF Residue & & 23.6 & 76.4 & 0.31 \\
\hline
\end{tabular}




\section{Figure Captions}

Figure 1. The weight loss and derivative weight loss curves for thermogravimetric analysis of Illinois $\# 6$ coal.

Figure 2. The low mass region $(0-200 \mathrm{~m} / \mathrm{z})$ of the TG-PI mass spectra at the derivative peak maxima for a) Wyodak at $447^{\circ} \mathrm{C}$. j) Pittsburgh $\# 8$ at $478^{\circ} \mathrm{C}$ and c) Pocahontas $\# 3$ at $526^{\circ} \mathrm{C}$.

Figure 3. The high $\mathrm{m} / \mathrm{z}$ region $(200-400 \mathrm{~m} / \mathrm{z})$ of the TG-PI mass spectra for a) Wyodak at $447^{\circ} \mathrm{C}$, b) Pittsburgh $\# 8$ at $478^{\circ} \mathrm{C}$ and c) Pocahontas $\# 3$ at $526^{\circ} \mathrm{C}$.

Figure 4. TG-PI-MS of Pittsburgh \#8 a) pyridine extract, b) residue after pyridine extraction and c) raw coal at $484^{\circ} \mathrm{C}$ (peak of volatile matter degradation).

Figure 5. Ion signal for methylnaphthalene $(\mathrm{m} / \mathrm{z}=142)$ during TG-PI-MS analysis in of Pittsburgh \#8 raw coal. pyridine extract and residue after pyridine extraction. 


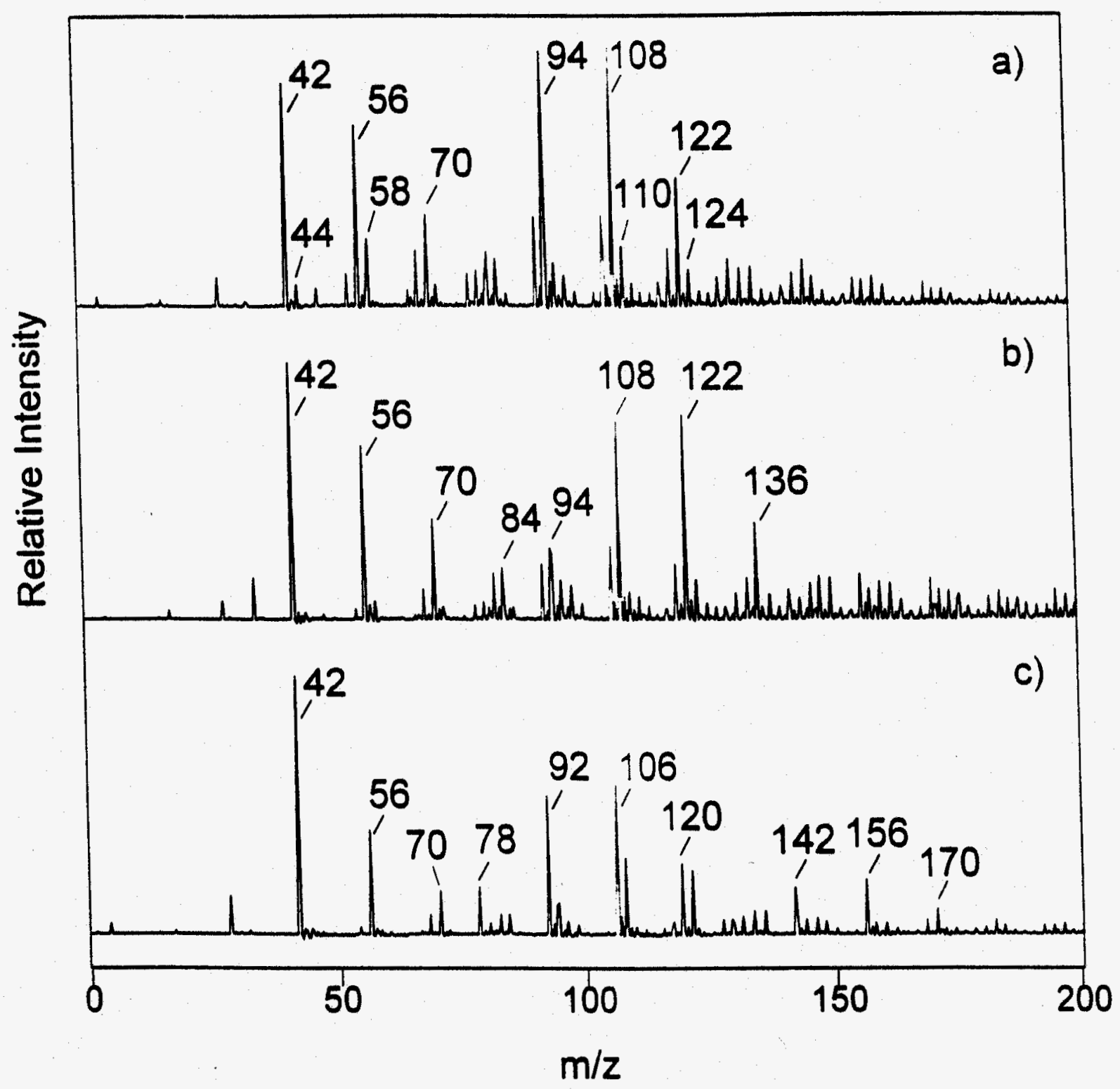

$F \circ 2$ 


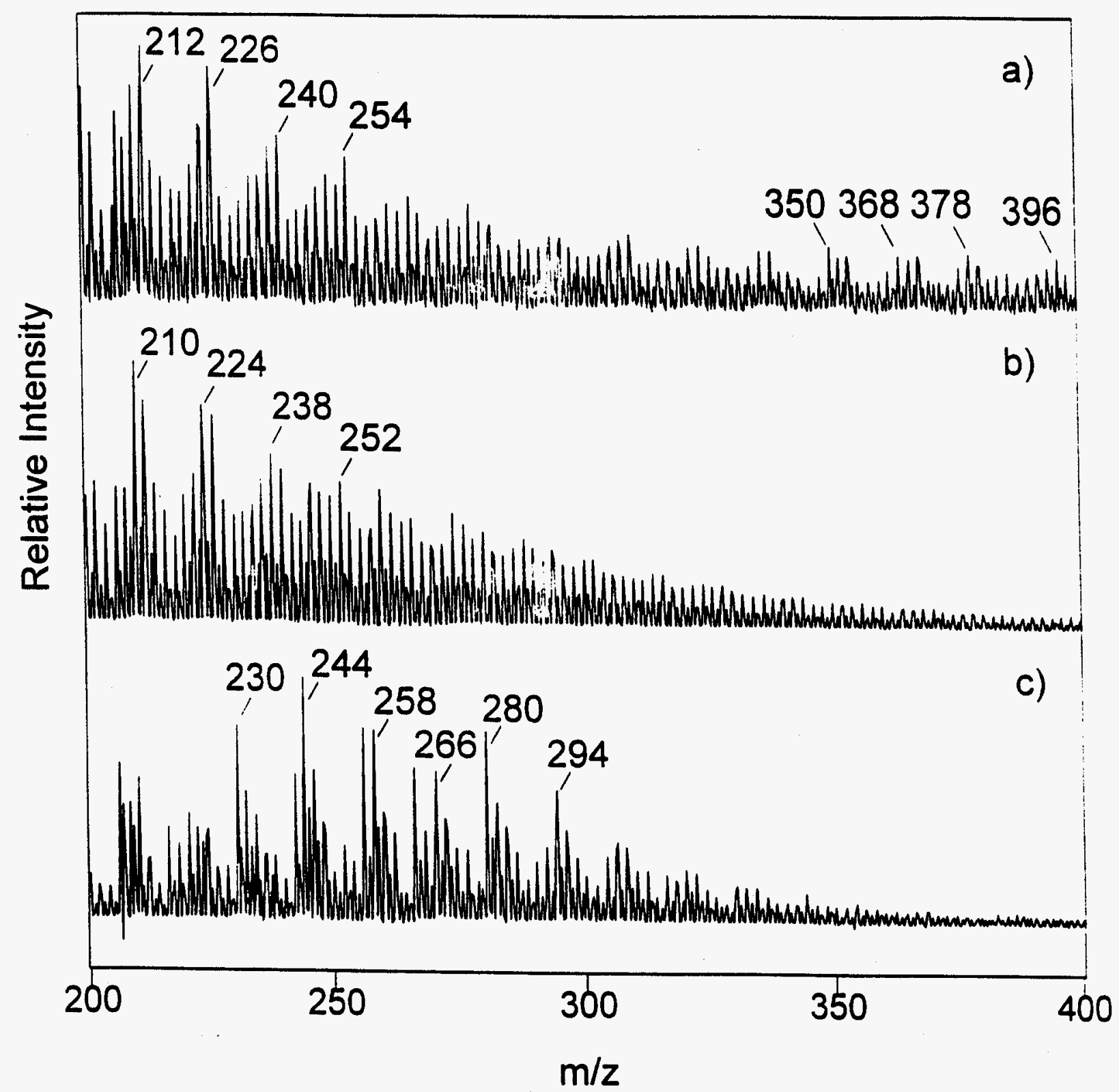

Fis: 


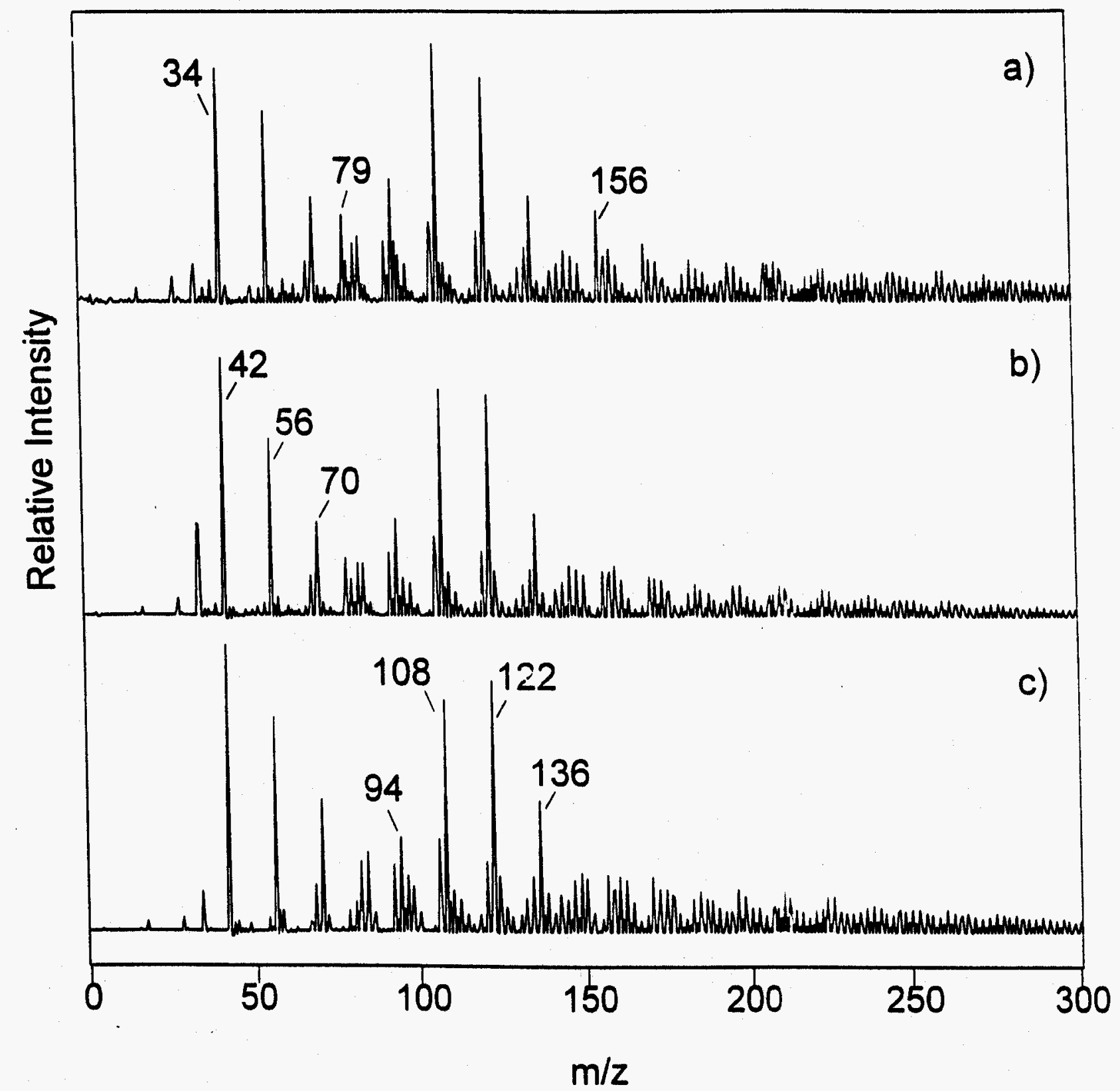

$? ?^{1}$ 


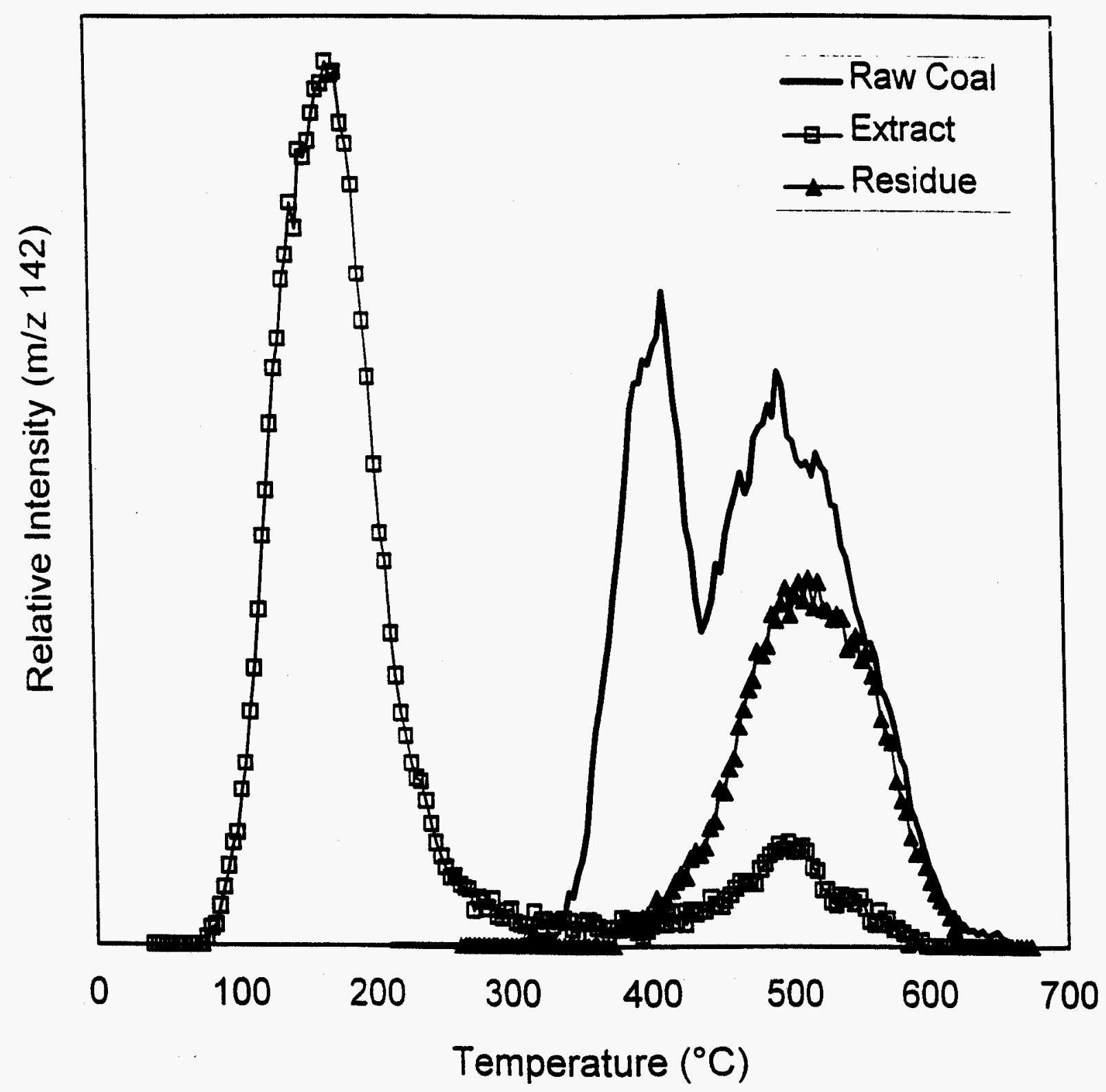

95 